(c) American Dairy Science Association, 2002.

\title{
Metaanalysis of Input/Output Kinetics in Lactating Dairy Cows
}

\author{
O. Martin and D. Sauvant \\ UMR INRA INA P-G, \\ Physiologie de la Nutrition et Alimentation, \\ 16 rue Claude Bernard, 75231 Paris Cedex 05, France
}

(Key words: metaanalysis, milk yield, dry matter intake, body weight)

\begin{abstract}
Abbreviation key: $\mathbf{C O}=$ concentrate, $\mathbf{E B W}=$ empty body weight, $\mathbf{F O}$ = forage, $\mathbf{M E I}=$ metabolizable energy intake, $\mathbf{M F C}=$ milk fat content, $\mathbf{M F Y}=$ milk fat yield, $\mathbf{M L C}=$ milk lactose content, $\mathbf{M L Y}=$ milk lactose yield, $\mathbf{M P C}=$ milk protein content, $\mathbf{M P Y}=$ milk protein yield, Multi = multiparous cow, Primi = primiparous cow, RMSE = root mean square error, $\mathbf{R M Y}=$ raw milk yield, YOP = year of publication
\end{abstract}

\section{INTRODUCTION}

The majority of articles published on dairy nutrition and feeding have dealt with short periods of experimentation or with designs where animals receive successive experimental diets (e.g., Latin square designs). These trials provide static data, which allows empirical models of the effect of a particular type of diet or allocation system on animal production responses to be calculated for a given period of lactation. However, lactation is not a set of successive independent periods; it needs to be considered as a dynamic process (Broster and Broster, 1984). This is of practical importance. Knowledge regarding the impact of feeding on the kinetics of lactation is necessary for the optimization of a feeding strategy subject to constraints of feed inventory and fluctuating input and output prices. It therefore appeared important to examine the kinetic patterns that characterize the course of the lactation (DMI, yield, BW) and to model their interactions. In particular, the purposes of this study were: 1) to evaluate the variability of the kinetic patterns, their evolution through years of experimentation, and their differences according to parity; and 2) to highlight the dependencies within a given kinetic or between different kinetics, which determine a particular profile.

To achieve this goal, we decided to build a database by pooling the results from published trials dealing with the dynamic features of feeding, lactation, and BW. This paper presents the major characteristics of this collection of curves and the main effects revealed by a first metaanalysis approach. 
c. Table 1. Origin, data availability of main production variables, and experimental designs of the 37 articles collected in the database. Variables: DMI, metabolizable energy intake (MEI), raw milk yield (RMY), FCM, milk fat, protein, and lactose yield and content (MFY, MPY, MLY, MFC, MPC, and MLC), and BW.

MF MP ML

$\begin{array}{lllllllllllll}\text { Article } & \text { Origin } & n^{1} & {\left[t_{0}-t_{3}\right]^{2}} & \text { DMI } & \text { MEI } & \text { RMY } & \text { FCM } & \overline{Y C} & \overline{Y C} & \overline{Y C} & \text { BW } & \text { Experimental design }\end{array}$

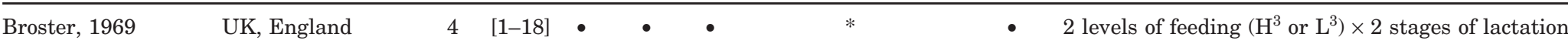

Broster, $1975 \quad$ UK, England $6 \quad[1-24] \quad \bullet \quad \bullet \quad \bullet \quad * *$

(wk [1-9] and [10-18]).

Broster, 1975

UK, England

Cowan, 1970

Zimbabwe

Decaen, 1970

France

DePeters, 1985

US, California

4 [1-40] •

2 [1-40]

DePeters, 1989

US, California

$6 \quad[1-15]$

Donker, 1983

US, Minnesota

$12 \quad[1-40]$

Everson, 1976

US, Wisconsin

2

Garnsworthy, 1982

UK, Scotland

$6 \quad[1-16]$

Holter, 1982

US, New Hampshire

10 [1-44] *

Holter, 1984

US, New Hampshire 3 [1-40] *

Holter, 1992

Holter, 1993

Johnson, 1977

Johnson, 1979

Johnson, 1983

US, New Hampshire 4 [1-43] *

US, New Hampshire 4 [1-40] *

Kertz, 1991

Kronfeld, 1980

Krohn, 1983

Lahr, 1983

Lodge, 1975

UK, England

UK, England

UK, England

US, Missouri

US, Pennsylvania

Denmark

US, Minnesota

Canada

Mohrenweiser, 1967 US, Minnesota

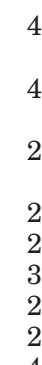

4
2
2
2
3
2
2
4
4

4 [1-40]
- 6 patterns of $\mathrm{CO}^{4}$ allocation: 3 levels of feeding $\left(\mathrm{L}, \mathrm{H}\right.$ or $\left.\mathrm{VH}^{3}\right)$ applied for 5 stages of lactation (wk [1-4], [5-8], [9-12], [13-16] and [17-24]).

- 4 TMR of different roughage content $(5 \%, 20 \%$, $35 \%$ or $50 \%$ in fresh matter basis).

- Secretion of fatty acids in 2 experimental farms. Parity $(\mathrm{P} \text { or } \mathrm{M})^{5} \times$ Number of daily milkings

( 2 or 3 times $)+2$ dietary protocols for M cows

milked 3 times daily.

- $\quad$ Parity $(\mathrm{P}$ or $\mathrm{M}) \times$ Type of $\mathrm{FO}^{4}$ (Chopped alfalfa hay: Cereal-vetch silage ratio: 100:0, 66:34 or

$34: 66$ in DM basis).

* Parity $(\mathrm{P}$ or $\mathrm{M}) \times 2$ sizes of cows (Small or Large $) \times 3$ rates of feeding $\mathrm{CO}$ according to milk produced above $9.1 \mathrm{~kg} / \mathrm{d}\left(\mathrm{L}, \mathrm{S}^{3}\right.$ or $\left.\mathrm{H}\right)$

- FO:CO ratio (Constant at 60:40 for wk [1-44] or variable at 50:50 for wk [1-21] and 65:35 for wk [22-44], in DM basis).

- $\quad 2$ identical trials: 3 BCS at calving (L: $[1,5-2,0], \mathrm{S}$ : $[2,5-3,0]$, H: $[3,5-4,0])$.

* Parity $(\mathrm{P}$ or $\mathrm{M}) \times 5$ programs of $\mathrm{CO}$ allocation according to milk produced.

* $\quad$ milk produced. Wk [9-40]: common decreasing program of $\mathrm{CO}$ allocation as percent of total CO consumed during wk [1-8].

* Parity $(\mathrm{P}$ or $\mathrm{M}) \times$ Rate of feeding $\mathrm{CO}$ according to group or individual requirements.

* $\quad$ Parity $(\mathrm{P}$ or $\mathrm{M}) \times$ Protein-Fat Bypass supplement $(0 \%$ or $6 \%$ of FCM produced.

- 4 programs of CO allocation (2 graded levels (same total amount during wk [1-20]), 2 fixed levels (L or H))

- 2 yield potential $(\mathrm{L}$ or $\mathrm{H})$ in wk $\{7\} \times 2$ levels of feeding $\mathrm{CO}$ in wk [9-20] (L or H).

- 2 programs of allocation of the same amount of CO in wk [6-20] (Graded or flat level).

- Compilation of 18 trials over 6 yr: $\mathrm{P}$ or $\mathrm{M}$.

Control vs diet including protected tallow.

3 energy concentrations in TMR (VH, H or L) in wk [1-24]. 2 diets of different moisture content (Alfalfa silage or hay). 2 levels of feeding prepartum (H or L).

- 2 types of FO (Early-cut or Late-cut alfalfa hay) $\times$ Prepartum or postpartum. 
Table 1. (continued) Origin, data availability of main production variables, and experimental designs of the 37 articles collected in the database. Variables: DMI, metabolizable energy intake (MEI), raw milk yield (RMY), FCM, milk fat, protein, and lactose yield and content (MFY, MPY, MLY, MFC, MPC, and MLC), and BW.

\begin{tabular}{|c|c|c|c|c|c|c|c|c|c|c|c|c|}
\hline & & & & & & & & $\mathrm{MF}$ & MP & ML & & \\
\hline Article & Origin & $\mathrm{n}^{1}$ & {$\left[\mathrm{t}_{0}-\mathrm{t}_{3}\right]^{2}$} & DMI & MEI & RMY & FCM & $\mathrm{YC}$ & YC & YC & BW & Experimental design \\
\hline Ostersen, 1997 & Denmark & 1 & [1-24] & • & - & - & - & $\bullet \bullet$ & $\bullet \bullet$ & $\bullet \bullet$ & - & Kinetics of milk constituents. \\
\hline Pinchasov, 1982 & Israel & 2 & [1-23] & - & • & - & & & & & - & Control vs diet including liquid whey. \\
\hline Rook, 1965 & UK, England & 2 & [1-45] & $\bullet$ & & $\bullet$ & $\bullet$ & $\bullet \bullet$ & $\bullet \bullet$ & $\bullet$ & $\bullet$ & $\begin{array}{l}2 \text { programs of CO allocation (Constant daily or milk } \\
\text { dependent amounts). }\end{array}$ \\
\hline Soder, 1999 & US, Pennsylvania & 4 & [1-13] & - & - & - & & & & & - & Control vs 3 diets including yeast, enzymes or yeast + enzymes. \\
\hline Staples, 1990 & US, Illinois & 3 & [1-9] & $\bullet$ & $\bullet$ & • & $\bullet$ & $\bullet \bullet$ & & & $\bullet$ & $\begin{array}{l}3 \text { groups according to ovarian activity (Early, late or } \\
\text { non-responders). }\end{array}$ \\
\hline Swanson, 1967 & US, Tennessee & 2 & [1-42] & - & & - & - & $\bullet$ & & & - & Restricted vs Ad libitum FO allocation. \\
\hline Taylor, 1984 & UK, Scotland & 6 & {$[2-22]$} & $\bullet$ & - & - & & & & & $\bullet$ & $\begin{array}{l}\text { Parity }(\mathrm{P} \text { or } \mathrm{M}) \times 3 \text { systems of } \mathrm{CO} \text { allocation } \\
\text { (Constant or decreasing daily amounts or fixed daily } \\
\text { amount according to mik produced in wk }\{2\}) \text {. }\end{array}$ \\
\hline Taylor, 1984 & UK, Scotland & 4 & [3-27] & $\bullet$ & $\bullet$ & - & & & & & - & $\begin{array}{l}2 \text { qualities of grass-silage ( } \mathrm{H} \text { or } \mathrm{L} \text { digestibility) } \\
\times 2 \text { systems of } \mathrm{CO} \text { allocation (Constant or variable } \\
\text { daily amounts). }\end{array}$ \\
\hline Tolkamp, 1998 & UK, Scotland & 3 & [2-22] & $\bullet$ & & - & $\bullet$ & $\bullet$ & $\bullet$ & $\bullet \bullet$ & $\bullet$ & $\begin{array}{l}2 \text { control groups (Access to } \mathrm{L} \text { or } \mathrm{H} \text { protein feeds) } \\
\text { an } 1 \text { choice group (access to both the } \mathrm{L} \\
\text { and } \mathrm{H} \text { protein feeds). }\end{array}$ \\
\hline Vérité, 1977 & France & 2 & [1-13] & - & - & - & & & & & - & Control vs formaldehyde treated oil-meals. \\
\hline Wallace, 1959 & New Zealand & 1 & [9-32] & - & & & - & & & & - & Study with identical twins (Lactating vs dry cow). \\
\hline Wiktorsson, 1971 & Sweden & 6 & {$[1-40]$} & $\bullet$ & $\bullet$ & & $\bullet$ & & & & $\bullet$ & $\begin{array}{l}3 \text { levels of feeding ( } \mathrm{L}, \mathrm{S} \text { or } \mathrm{H}) \text { over } 3 \text { consecutive experimental } \\
\text { lactations. }\end{array}$ \\
\hline Wiktorsson, 1973 & Sweden & 2 & [1-8] & - & - & & - & & & & - & Ad libitum vs restricted feeding of hay and $\mathrm{CO}$. \\
\hline Wohlt, 1978 & US, Illinois & 5 & [1-43] & • & & • & • & $\bullet$ & $\bullet$ & & • & $\begin{array}{l}5 \mathrm{CO} \text { mixtures (No supplemental } \mathrm{N} \text {, urea, L or } \mathrm{H} \text { soybean meal, } \\
\text { or urea }+\mathrm{L} \text { soybean meal). }\end{array}$ \\
\hline Wohlt, 1991 & US, New Jersey & 4 & {$[1-18]$} & $\bullet$ & $\bullet$ & $\bullet$ & $\bullet$ & $\bullet \bullet$ & $\bullet \bullet$ & & $\bullet$ & $\begin{array}{l}\text { Control diet }(12 \% \mathrm{CP}) \text { vs } 3 \text { protein sources }(16 \% \mathrm{CP} \text { with } \\
\text { soybean meal, fish meal or corn gluten meal). }\end{array}$ \\
\hline
\end{tabular}

-Data recorded weekly over the experimental period.

*Data recorded monthly over the experimental period.

${ }^{1}$ Number of treatment groups included in the database.

${ }^{2}$ Recorded experimental period in weeks after calving; $\mathrm{t}_{0}=$ first record, $\mathrm{t}_{3}=$ last record.

${ }^{3} \mathrm{VH}=$ Very high, $\mathrm{H}=$ High, $\mathrm{S}=$ Standard, L = Low.

${ }^{4} \mathrm{CO}=$ concentrate, $\mathrm{FO}=$ forage.

${ }^{5} \mathrm{P}=$ primiparous, $\mathrm{M}=$ multiparous 


\section{MATERIALS AND METHODS}

\section{Compilation of the Literature}

Articles and experimental designs. Experimental factors and results published in 37 articles covering input/output kinetics of lactating dairy cows were collected in the database. The articles, published between 1959 and 1999, reported trials performed in North America $(n=17)$, Europe $(n=17)$, Asia $(n=1)$, Africa $(\mathrm{n}=1)$, and Oceania $(\mathrm{n}=1$; Table 1$)$. The criteria used for inclusion were the existence of data concerning the kinetics of DMI $(\mathrm{kg} / \mathrm{d})$ and/or metabolizable energy intake (MEI, Mcal/d), raw milk yield (RMY, kg/d) and/ or $4 \%$ FCM yield $(\mathrm{kg} / \mathrm{d})$, and BW $(\mathrm{kg})$, all of which had to have been recorded for at least the first $8 \mathrm{wk}$ of lactation. When available, the kinetics of milk fat yield (MFY, g/d) or content (MFC, g/kg) [MFC $=$ MFY/RMY], milk protein yield (MPY, g/d) or content (MPC, g/kg) $[\mathrm{MPC}=\mathrm{MPY} / \mathrm{RMY}]$, and milk lactose yield (MLY, g/ d) or content (MLC, g/kg) [MLC = MLY/RMY] were recorded (Table 1). The data sets used were weekly (32 articles) or monthly means (five articles) of daily records. Most of the data were published as graphs: consequently, they were stored in the database after digitalization. Each graph was scanned (IrfanView 3.36, Irfan Skiljan, http://www.irfanview.com/), and the picture file was incorporated as the background of an indexed graphical interface. Relative positions and scales of the picture axis were used to calibrate $(\mathrm{X}, \mathrm{Y})$ coordinates, and data points were translated into numerical values. These calculations were performed with Excel 2000 (Microsoft Corporation). This digitalization procedure was tested on simulated graphs. This method was found to be unbiased and accurate with less than $1 \%$ error.

The 37 articles included 140 treatments that were applied to groups of 3 to 277 cows ( $16.0 \pm 27.6$ animals/ treatment group, mean \pm SD). Most of these studies were aimed at investigating the effect of defined feeding strategies or types of diet on dynamic animal responses (Table 1). Cows were generally blocked into groups according to parity, BW, breed, calving date, and milk yield of previous lactation or early performance from the current lactation. They were then randomly assigned to each treatment group, generally at calving, and maintained in carefully controlled conditions of feeding and management over the experimental periods.

Animals and housing. The experiments were mainly conducted with Holstein-Friesian cows. However, the two trials reported by Wiktorsson $(1971,1973)$ were performed with cows of the Swedish Red and White breed. Ayrshire cows (pure- or cross-bred) comprised half of the livestock used in the experiment of
Garnsworthy (1982). Moreover, Ayrshire and Guernsey breeds were involved in the trial of Everson (1976), and Jersey cows in the trial of Swanson (1962). Within a treatment group, animals were predominantly of the same parity: 51 treatments used primiparous cows (Primi) and 89 multiparous cows (Multi; including 10 heterogeneous treatment groups with between 25 to $34 \%$ Primi which were treated as Multi). Animals were mostly housed individually in tie stalls or stanchion barns.

Diets and feeding. Cows from each treatment group were individually fed during one or several experimental subperiods according to a given nutritional plan. The dietary treatments were designed using combinations of the type of diet and its allocation system. The feeding regimens used three basic types of feeds: forage (FO), concentrate (CO), and TMR. The feed allocation systems were applied to either FO, CO or TMR, and there were four major types: 1) Restricted: allowance according to a predetermined flat rate or gradual increase up to a ceiling during the experimental period; 2) Ad libitum: feed allowance to appetite (seven papers reported a standard daily ort of 5 to $12 \%$ on a DM basis allowed); 3) Fitted: feed allowance adjusted at given intervals to current yield of milk (for production requirements) and/or BW (for maintenance requirements) - the rate of feeding per unit output (kg FCM, $\mathrm{kg}$ RMY, $\mathrm{kg} \mathrm{BW}$, or $\mathrm{kg} \mathrm{BW}{ }^{0.75}$ ) was constant throughout the whole experimental period or gradually changed; and 4) Mixed: allowance of part of the ration in a restricted manner, the remainder being fed in a fitted manner. As a codifying rule, if a treatment group was fed more than $50 \%$ of the diet (in $\mathrm{kg} \mathrm{DM}$ ) ad libitum, fitted, or restricted, it was labeled as such. Since the fitted system was applied on the basis of expected nutrient requirements, the rate of feeding per unit output determined the allocation scheme. Thus, depending on the rate, the fitted system could be close to the ad libitum system (liberal allocation) or close to the restricted system (limited allocation). A total of 111 different feedstuffs were used in these experiments: 29 TMR, 38 FO, and $44 \mathrm{CO}$. The FO were either hays (mainly meadow grass or alfalfa), grass or corn silages. The $\mathrm{CO}$ were mixtures of cereals (mainly barley, corn or oats), cereal byproducts (mainly wheat bran, brewers grains or corn gluten meal), oil meals (mainly soybean meal, peanut meal, rapeseed meal, coconut meal or cotton meal), and agro-industrial byproducts (mainly sugar beet pulp or molasses). The TMR were mixtures of roughages (mainly corn silage, meadow or alfalfa hay, or grass silage) and energy feeds (commercial dairy compound or mixtures of barley, corn, sugar beet pulp, brewers grains, and oil meals). All the available data concerning 
the chemical composition of feeds were systematically recorded in the database.

Analysis and records. In the majority of cases, feed allowance and intake were weighed daily. In most of the trials, samples of feed were collected weekly for pooled monthly chemical analyses, which were carried out according to conventional AOAC methods. Cows were generally machine-milked twice daily, except in Pinchasov (1982) and three treatment groups in DePeters (1985) for which cows were milked three times a day. Analysis of milk composition was generally performed monthly on weekly-pooled frozen samples. MFC was determined using the Babcock method (in the United States), the Gerber method (in Europe), or by infrared analysis (in the 1990's). MPC was assayed using Kjeldahl determination $(\mathrm{N} \times 6.38)$, orange $\mathrm{G}$ dye binding method (Udy, 1956), amido-black colorimetry (Posthumus, 1960) or infrared analysis. The MLC content was determined according to Somogyi (1952), Rook and Line (1961), or infrared analysis. The energy values of feeds were calculated or estimated by the authors according to the method generally used in the corresponding country. Animals were usually weighed twice per month on 2 consecutive $d$ at the same hour.

\section{Data Analysis}

Additional variables. The percentages of $\mathrm{FO}$ and $\mathrm{CO}$ in diets allowed the calculation of the DMI of FO $(\mathrm{kg} / \mathrm{d})$, and CO $(\mathrm{kg} / \mathrm{d})$. DMI of the TMR was also noted $(\mathrm{kg} / \mathrm{d})$. The BW was used as such and also corrected for expected changes in gastrointestinal fill related to DMI, where a mean digestive tract content correction factor of $4 \mathrm{~kg} / \mathrm{kg}$ DMI was used, assuming an increase in the weight of the reticulo-rumen content of $3 \mathrm{~kg} / \mathrm{kg}$ DMI (Rémond, 1988) and an additional increase in intestinal content of $1 \mathrm{~kg} / \mathrm{kg}$ DMI (Chilliard et al., 1987) [Empty BW $(\mathbf{E B W}, \mathrm{kg})=\mathrm{BW}(\mathrm{kg})-4 \times \mathrm{DMI}(\mathrm{kg})]$. This correction was made to reduce the variability in the evolution of BW, especially in early lactation when DMI increased, and to estimate the real loss and gain of body reserves.

Treatment group general outcomes. Letting $\mathrm{Y}$ be the response variable (DMI, FO DMI, CO DMI, TMR DMI, MEI, RMY, FCM, MFY, MFC, MPY, MPC, MLY, MLC, BW, or EBW), the mean values of $Y$ between wk 1 and 8 of lactation (Y[1-8]) were calculated for each treatment group. This measure was regarded as an overall level indicator of the Y-kinetic, from a static standpoint.

Two sequential mixed models were fitted with Proc MIXED of SAS (1992) to determine the effects of parity and year of publication (YOP) on Y[1-8]. The first model focuses on the effect of parity on the slope of the regression:

$$
\mathrm{Y}[1-8]_{i j k}=P_{j}+t_{k}+B_{j} \cdot Y O P+e_{i j k},
$$

where,

$$
\begin{aligned}
\mathrm{P}_{\mathrm{j}}= & \text { fixed effect of parity group } \mathrm{j}(\mathrm{j}=1,2+), \\
\mathrm{t}_{\mathrm{k}}= & \text { random effect of trial } \mathrm{k}(\text { various number } \\
& \text { of trial according to } \mathrm{Y}[1-8]), \\
\mathrm{B}_{\mathrm{j}}= & \text { regression coefficient of } \mathrm{Y}[1-8] \text { on YOP for } \\
& \text { parity group } \mathrm{j}, \\
\mathrm{e}_{\mathrm{ijk}}= & \text { error term } \sim \mathrm{N}\left(0, \sigma^{2}{ }_{\mathrm{e}}\right) .
\end{aligned}
$$

A significant effect of $P_{j}$ indicated that the intercepts of the slope of the linear regression of Y[1-8] on YOP were different from zero for at least one parity group. Therefore, a second model was fitted as follows:

$$
\mathrm{Y}[1-8]_{i j k}=\mu+\mathrm{P}_{\mathrm{j}}+\mathrm{t}_{\mathrm{k}}+\left(\beta_{0}+\beta_{\mathrm{j}}\right) \cdot \mathrm{YOP}+\mathrm{e}_{\mathrm{ijk}},
$$

where symbols are as previously defined with the following changes:

$$
\begin{aligned}
\mu= & \text { overall mean, } \\
\beta_{0}= & \text { overall regression coefficient of } \mathrm{Y}[1-8] \text { on } \\
& \text { YOP } \\
\beta_{\mathrm{j}}= & \text { deviation of regression coefficient of } \mathrm{Y}[1- \\
& \text { 8] on YOP from the overall regression coef- } \\
& \text { ficient for parity group j. }
\end{aligned}
$$

A significant $\beta_{\mathrm{j}}$ effect indicated that the slope of $\mathrm{Y}[1-8]$ on YOP was different for parity groups. Because of the unequal number of lactation (cow-year) between treatment groups and since the standard errors of $Y$ by week were generally not known, least-squares were weighted with $\sqrt{\mathrm{N}_{\mathrm{i}}}$, where $\mathrm{N}_{\mathrm{i}}$ was the number of lactations of treatment group i.

This first statistical model was aimed at giving an overview of the database without respect of dynamic aspects of lactation.

Modeling kinetics. Among the group of curves associated with lactation in the dairy cow, the kinetics of RMY have been most often described and modeled with time dependent functions (see reviews of Rowlands et al., 1982; Masselin et al., 1987; Papajcsik and Bodero, 1988; Rook et al., 1993). Among them, the gamma function $\mathrm{y}(\mathrm{t})=\mathrm{a} \cdot \mathrm{t}^{\mathrm{b}} \cdot \mathrm{e}^{-\mathrm{ct}}$ proposed by Wood $(1967,1968,1969$, 1977) has been extensively used to summarize the pattern of lactational performance. In this function, $y(t)$ is the average daily milk yield in wk $t$ of lactation, and $a, b$, and $c$ are positive parameters that determine the scale and shape of the curve. While improving the pion- 
eering work of Wood, several authors have developed alternative forms of this model (Kuck et al, 1976; Cobby and Le Du, 1978; Dhanoa, 1981; Schneeberger, 1981). More recently, Goodall and Sprevak extended the fitting properties of Wood's model with stochastic (1984) and recursive (1985) procedures. Since the 1980's, numerous authors have suggested other mathematical approaches for fitting the milk yield $\times$ time data, either empirical (Emmans et al., 1983; Grossman and Koops, 1988; Morant and Gnanasakthy, 1989; Rook et al., 1993; Grossman et al., 1999), mechanistic (Neal and Thornley, 1983; Dijkstra et al., 1997), nonparametric (Elston et al., 1989) or autoregressive (Dhanoa and Le Du, 1982; Deluyker et al., 1990). Much less research has been undertaken on specific mathematical models to fit other curves characterizing the lactation profile. Nevertheless, several authors have proposed an application of their milk model to milk constituent yields (Schneeberger, 1979; Morant and Gnanasakthy, 1989) or contents (Wood, 1976), or to BW changes (Wood, 1979; Emmans et al., 1983). Stanton et al. (1992) proposed a statistical mixed model for milk, fat, and protein lactation curves. When fitting intake kinetics, Ostergaard (1979) proposed, in the context of ad libitum intake, to use the function $y(t)=a-b \cdot e^{-c t}-d \cdot t$, where $y(t)$ is the average daily DMI in wk t, and $a, b$, and c are positive parameters which determine the scale and shape of the curve. In the present paper, we wanted to use 1) the same model to fit the kinetics of all variables $\mathrm{Y}$, and 2) a model which parameters quantified a specific and concrete aspect of the global pattern of the curve. This model was aimed at summarizing all curves with the same analytical rule in equivalent vectors of parameters. Observed kinetics of Y over the recorded experimental period [t0; t3] $\left(t_{0} \geq 1\right.$ and $\left.t_{3} \leq 45\right)$ of each treatment group were then summarized with the following triphasic model (only works concerning DMI, RMY, EBW, and MFY are considered in the present paper).

$$
\mathrm{Y}^{*}(\mathrm{t})= \begin{cases}\mathrm{Y}_{\mathrm{C}}+\mathrm{k}_{\mathrm{E}} \cdot \mathrm{t} & \text { If } \mathrm{t} \epsilon\left[\mathrm{t}_{0} ; \mathrm{t}_{1}\right] \\ \mathrm{Y}_{\mathrm{M}} & \text { If } \mathrm{t} \epsilon\left[\mathrm{t}_{1} ; \mathrm{t}_{2}\right] \\ \mathrm{Y}_{\mathrm{M}}+\mathrm{k}_{\mathrm{L}} \cdot\left(\mathrm{t}_{2}-\mathrm{t}\right) & \text { If } \mathrm{t} \epsilon\left[\mathrm{t}_{2} ; \mathrm{t}_{3}\right]\end{cases}
$$

where,

$$
\begin{aligned}
\mathrm{Y}^{*}= & \text { predicted value of DMI, RMY, MFY, and } \\
& \text { EBW, } \\
\mathrm{t}= & \text { time, in weeks of lactation from calving, } \\
{\left[\mathrm{t}_{0} ; \mathrm{t}_{1}\right]=} & \text { early stage of lactation, } \\
{\left[\mathrm{t}_{1} ; \mathrm{t}_{2}\right]=} & \text { middle stage of lactation, } \\
{\left[\mathrm{t}_{2} ; \mathrm{t}_{3}\right]=} & \text { late stage of lactation, } \\
\mathrm{k}_{\mathrm{E}}= & \text { slope of } \mathrm{Y} \text { as a function of time in early } \\
& \text { stage of lactation }\left(\mathrm{k}_{\mathrm{E}} \geq 0 \text { for } \mathrm{Y}=\mathrm{DMI},\right. \\
& \text { RMY, and MFY; } \left.\mathrm{k}_{\mathrm{E}} \leq 0 \text { for } \mathrm{Y}=\mathrm{EBW}\right),
\end{aligned}
$$

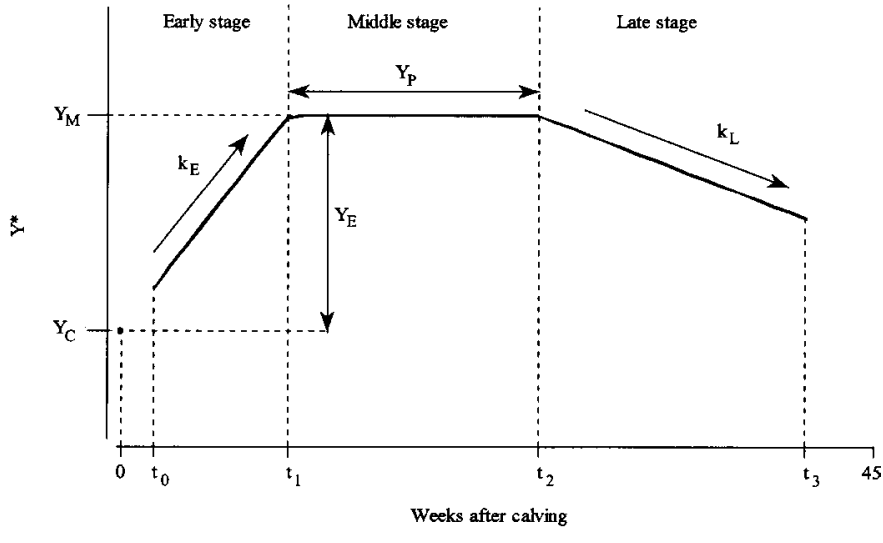

Figure 1. Model proposed by Grossman et al. (1999) (smoothing logistic transition between intersecting straight lines):

$$
\begin{aligned}
\mathrm{Y}^{*}(\mathrm{t})= & \mathrm{Y}_{\mathrm{M}}+\mathrm{k}_{\mathrm{E}}\left(\mathrm{t}-\mathrm{t}_{1}\right)-\mathrm{r}_{1} \mathrm{k}_{\mathrm{E}} \operatorname{Ln}\left[\frac{\mathrm{e}^{\mathrm{t} / \mathrm{r}_{1}}+\mathrm{e}^{\mathrm{t}_{1} / \mathrm{r}_{1}}}{1+\mathrm{e}^{\mathrm{t}_{1} / \mathrm{r}}}\right] \\
& +\mathrm{r}_{2} \mathrm{k}_{\mathrm{L}} \operatorname{Ln}\left[\frac{\mathrm{e}^{\mathrm{t} / \mathrm{r}_{2}}+\mathrm{e}^{\mathrm{t}_{2} / \mathrm{r}_{2}}}{1+\mathrm{e}^{\mathrm{t}_{2} / \mathrm{r}_{2}}}\right]
\end{aligned}
$$

where $\mathrm{Y}_{\mathrm{M}}=$ plateau value of $\mathrm{Y}$ in middle stage, $\mathrm{k}_{\mathrm{E}}=$ slope of $\mathrm{Y}$ in early stage, $t_{1}=$ upper bound of early stage, $r_{1}$ and $r_{2}=$ durations of smoothing transition between linear phases set to $0.15 \mathrm{wk}, \mathrm{k}_{\mathrm{L}}=$ slope of $\mathrm{Y}$ in late stage, and $t_{2}=$ upper bound of middle stage. Additional parameters: $Y_{C}=$ extrapolated value of $Y$ at calving time $(t=0), Y_{E}$ $=$ total variation in $\mathrm{Y}$ during early stage, $\mathrm{Y}_{\mathrm{P}}=$ duration of middle stage.

$$
\begin{aligned}
\mathrm{k}_{\mathrm{L}}= & \text { slope of } \mathrm{Y} \text { as a function of time in late } \\
& \text { stage of lactation }\left(\mathrm{k}_{\mathrm{L}} \leq 0 \text { for } \mathrm{Y}=\mathrm{DMI}, \mathrm{RMY},\right. \\
& \text { and } \left.\mathrm{MFY} ; \mathrm{k}_{\mathrm{E}} \geq 0 \text { for } \mathrm{Y}=\mathrm{EBW}\right), \\
\mathrm{Y}_{\mathrm{C}}= & \text { extrapolated value of } \mathrm{Y} \text { for } \mathrm{t}=0 \text {, calving } \\
& \text { time, } \\
\mathrm{Y}_{\mathrm{M}}= & \text { plateau value of } \mathrm{Y} \text { in middle stage lacta- } \\
& \text { tion. }
\end{aligned}
$$

Using the above model, each stage was summarized by its linear trend: increasing or decreasing for early and late stages, constant for the middle stage. In order to build a smooth function from the linear equations system [3], we used the smoothing logistic transition between intersecting straight lines proposed by Koops and Grossman (1993) and employed by Grossman (1999) in the case of $Y=R M Y$. Thus, the model finally used for each $\mathrm{Y}$ variable was (Figure 1):

$$
\begin{aligned}
Y^{*}(t)=Y_{M} & +k_{E}\left(t-t_{1}\right)-r_{1} k_{E} \operatorname{Ln}\left[\frac{e^{t / r_{1}}+e^{t_{1} / r_{1}}}{1+e^{t_{1} / r_{1}}}\right] \\
& +r_{2} k_{L} \operatorname{Ln}\left[\frac{e^{t / r_{2}}+e^{t_{2} / r_{2}}}{1+e^{t_{2} / r_{2}}}\right]
\end{aligned}
$$

In equation [4], $r_{1}$ and $r_{2}$ were the measures of duration of smoothing transition between linear tendencies, 
from early to middle, and middle to late stages respectively. These two parameters governed the curvature of the model, with large values leading to smoother transitions. The values of the parameters $r_{1}$ and $r_{2}$ were fixed at $0.15 \mathrm{wk}$, which is equivalent to the value of 1 d used by Grossman (1999) for daily datasets. This low value only conferred smoothing properties to these parameters. As seen in Figures 2a and 2b, increasing

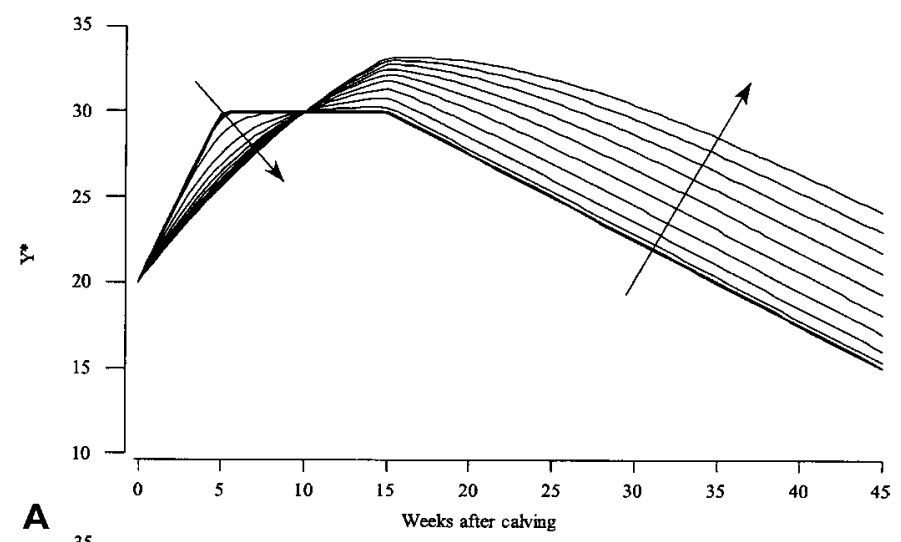

A

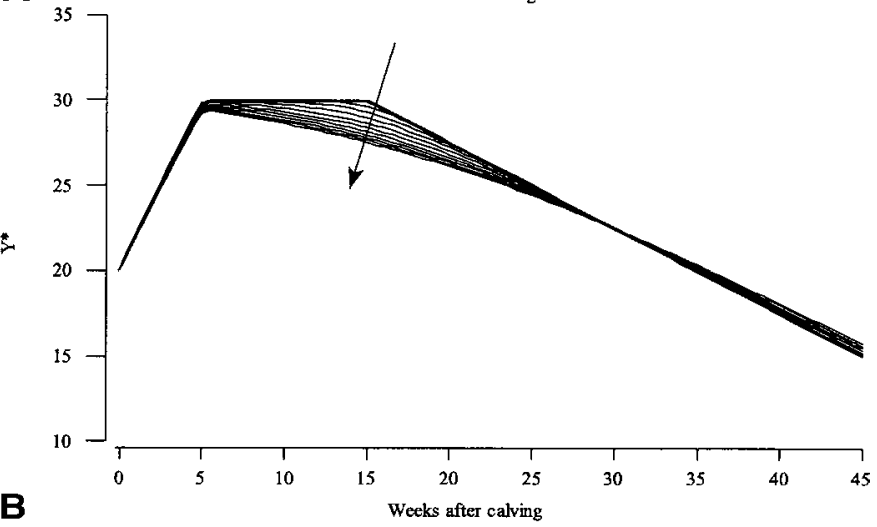

Figure 2a. Effect of increasing values of parameter $r_{1}$ on the shape of the model proposed by Grossman et al. (1999):

$$
\begin{aligned}
Y^{*}(t)= & Y_{M}+k_{E}\left(t-t_{1}\right)-r_{1} k_{E} \operatorname{Ln}\left[\frac{e^{t / r_{1}}+e^{t_{1} / r_{1}}}{1+e^{t_{1} / r_{1}}}\right] \\
& +r_{2} k_{L} \operatorname{Ln}\left[\frac{e^{t / r_{2}}+e^{t_{2} / r_{2}}}{1+e^{t_{2} / r_{2}}}\right]
\end{aligned}
$$

(Model parameters: $\mathrm{Y}_{\mathrm{M}}=30.0, \mathrm{k}_{\mathrm{E}}=2.0, \mathrm{k}_{\mathrm{L}}=-0.5, \mathrm{t}_{1}=5, \mathrm{t}_{2}=15, \mathrm{r}_{1}$ $\left.=\{0.15,1,2,3, \ldots, 9\}, \mathrm{r}_{2}=0.15\right)$.

Figure 2b. Effect of increasing values of parameter $r_{2}$ on the shape of the model proposed by Grossman et al. (1999):

$$
\begin{aligned}
\mathrm{Y}^{*}(\mathrm{t})=\mathrm{Y}_{\mathrm{M}} & +\mathrm{k}_{\mathrm{E}}\left(\mathrm{t}-\mathrm{t}_{1}\right)-\mathrm{r}_{1} \mathrm{k}_{\mathrm{E}} \operatorname{Ln}\left[\frac{\mathrm{e}^{\mathrm{t} / \mathrm{r}_{1}}+\mathrm{e}^{\mathrm{t}_{1} / \mathrm{r}_{1}}}{1+\mathrm{e}^{\mathrm{t}_{1} / \mathrm{r}_{1}}}\right] \\
& +\mathrm{r}_{2} \mathrm{k}_{\mathrm{L}} \operatorname{Ln}\left[\frac{\mathrm{e}^{\mathrm{t} / \mathrm{r}_{2}}+\mathrm{e}^{\mathrm{t}_{2} / \mathrm{r}_{2}}}{1+\mathrm{e}^{\mathrm{t}_{2} / \mathrm{r}_{2}}}\right]
\end{aligned}
$$

(Model parameters: $\mathrm{Y}_{\mathrm{M}}=30.0, \mathrm{k}_{\mathrm{E}}=2.0, \mathrm{k}_{\mathrm{L}}=-0.5, \mathrm{t}_{1}=5, \mathrm{t}_{2}=15, \mathrm{r}_{1}$ $=0.15, \mathrm{r}_{2}=\{0.15,1,2,3, \ldots, 9\}$ ). values of $r_{1}$ and $r_{2}$ spread the duration of the smooth transition and then distorted the curve from the pattern of Figure 1 (all the other parameters' values were constant). The model set to an arbitrary slightly smooth curve $(1 \mathrm{~d})$ is locked on the fitting pattern of Figure 1, with a valid assumption of the middle stage being a plateau at the level of $Y_{M}$, beginning in wk $t_{1}$ and ending in wk $t_{2}$. Hence, the model was completely defined with the vector $\left[\mathrm{Y}_{\mathrm{M}}, \mathrm{t}_{1}, \mathrm{t}_{2}, \mathrm{k}_{\mathrm{E}}, \mathrm{k}_{\mathrm{L}}\right]$ and the constraint $\mathrm{t}_{2} \geq \mathrm{t}_{1}$. Estimates for these five parameters were determined using nonlinear least squares methods using Proc NLIN of SAS (1992). Observed dependent variables were weekly means from the digitized dataset. No particular precaution was taken in the fitting procedure to deal with the natural serial correlation between observations. The coefficient of determination $\left(R^{2}\right)$ and the root mean square error (RMSE) were computed and used as goodness-of-fit indicators. The asymptotic standard errors of the parameter estimates $\mathrm{Y}_{\mathrm{M}}, \mathrm{t}_{1}, \mathrm{t}_{2}$, $\mathrm{k}_{\mathrm{E}}, \mathrm{k}_{\mathrm{L}}$ were denoted $\mathrm{s}_{\mathrm{M}}, \mathrm{s}_{1}, \mathrm{~s}_{2}, \mathrm{~s}_{\mathrm{kE}}$, and $\mathrm{s}_{\mathrm{kL}}$ respectively. The total variation in $\mathrm{Y}\left(\mathrm{Y}_{\mathrm{E}}\right.$, in the unit of $\left.\mathrm{Y}\right)$ during the early stage and its standard error $\mathrm{s}_{\mathrm{E}}$ were estimated with the following formulas:

$$
\begin{gathered}
\mathrm{Y}_{\mathrm{E}}=\mathrm{k}_{\mathrm{E}} \cdot \mathrm{t}_{1}+\operatorname{cov}\left(\mathrm{k}_{\mathrm{E}}, \mathrm{t}_{1}\right), \\
\mathrm{s}_{\mathrm{E}}^{2} \approx \mathrm{k}_{\mathrm{E}}^{2} \mathrm{~s}_{1}^{2}+\mathrm{t}_{1}^{2} \mathrm{~s}_{\mathrm{kE}}^{2}+2 \mathrm{k}_{\mathrm{E}} \mathrm{t}_{1} \operatorname{cov}\left(\mathrm{k}_{\mathrm{E}}, \mathrm{t}_{1}\right),
\end{gathered}
$$

where $\operatorname{cov}\left(\mathrm{k}_{\mathrm{E}}, \mathrm{t}_{1}\right)$ is the asymptotic covariance of parameter estimates $k_{E}$ and $t_{1}$. The extrapolated value of $\mathrm{Y}$ at calving $\left(\mathrm{Y}_{\mathrm{C}}\right.$, in unit of $\left.\mathrm{Y}\right)$ and its standard error $\mathrm{s}_{\mathrm{C}}$ were estimated with the following formulas:

$$
\mathrm{Y}_{\mathrm{C}}=\mathrm{Y}_{\mathrm{M}}-\mathrm{Y}_{\mathrm{E}}
$$

$$
\mathrm{s}_{\mathrm{C}}^{2} \approx \mathrm{s}_{\mathrm{M}}^{2}+\mathrm{k}_{\mathrm{E}}^{2} \mathrm{~s}_{1}^{2}+\mathrm{t}_{1}^{2} \mathrm{~s}_{\mathrm{kE}}^{2}-2 \mathrm{k}_{\mathrm{E}} \operatorname{cov}\left(\mathrm{Y}_{\mathrm{M}}, \mathrm{t}_{1}\right)
$$$$
-2 \mathrm{t}_{1} \operatorname{cov}\left(\mathrm{Y}_{\mathrm{M}}, \mathrm{k}_{\mathrm{E}}\right)-2 \mathrm{k}_{\mathrm{E}} \mathrm{t}_{1} \operatorname{cov}\left(\mathrm{t}_{1}, \mathrm{k}_{\mathrm{E}}\right) \text {, }
$$

where $\operatorname{cov}\left(\mathrm{Y}_{\mathrm{M}}, \mathrm{t}_{1}\right)$ and $\operatorname{cov}\left(\mathrm{Y}_{\mathrm{M}}, \mathrm{k}_{\mathrm{E}}\right)$ are the asymptotic covariances of parameter estimates $\mathrm{Y}_{M}$ and $t_{1}$, and $\mathrm{Y}_{\mathrm{M}}$ and $\mathrm{k}_{\mathrm{E}}$ respectively. Grossman (1999) proposed to define the persistency of RMY as the duration of the middle stage. We employed this terminology for all kinetics. The persistency of $\mathrm{Y}\left(\mathrm{Y}_{\mathrm{P}}\right.$, in wk) and its standard error $\mathrm{SP}_{\mathrm{P}}$ were estimated with the following formulas:

$$
\begin{gathered}
\mathrm{Y}_{\mathrm{P}}=\mathrm{t}_{2}-\mathrm{t}_{1}, \\
\mathrm{~s}_{\mathrm{P}}^{2} \approx \mathrm{s}_{1}{ }^{2}+\mathrm{s}_{2}{ }^{2}-2 \cdot \operatorname{cov}\left(\mathrm{t}_{1}, \mathrm{t}_{2}\right),
\end{gathered}
$$

where $\operatorname{cov}\left(t_{1}, t_{2}\right)$ is the asymptotic covariance of parameter estimates $t_{1}$ and $t_{2}$. Estimates of parameters were used for further analysis if the following conditions were respected: 
$t_{1}: t_{1} \neq t_{0}$ (early stage detected)

$t_{2}: t_{2} \neq t_{0}$ and $t_{2} \neq t_{3}$ (middle stage detected)

$\mathrm{k}_{\mathrm{E}}: \mathrm{t}_{1} \neq \mathrm{t}_{0}$ (early stage detected)

$k_{L}: t_{3}-t_{2}>3$ (slope estimated over at least 3 wk)

$\mathrm{Y}_{\mathrm{M}}: \mathrm{t}_{3}>\mathrm{t}_{1}$ (end of early stage detected)

$\mathrm{Y}_{\mathrm{E}}$ and $\mathrm{Y}_{\mathrm{C}}: \mathrm{Y}_{\mathrm{M}}>\mathrm{Y}_{\mathrm{C}}$ (valid estimate of a positive value of $\left.\mathrm{Y}_{\mathrm{E}}\right)$

$\mathrm{Y}_{\mathrm{P}}: \mathrm{t} 2 \neq \mathrm{t} 3$ (non null persistency)

Finally a database was created with, for each Y-kinetic of each treatment group, the vector of valid estimates of eight parameters $\mathrm{Y}_{\mathrm{C}}, \mathrm{Y}_{\mathrm{E}}, \mathrm{Y}_{\mathrm{M}}, \mathrm{k}_{\mathrm{E}}, \mathrm{k}_{\mathrm{L}}, \mathrm{t}_{1}, \mathrm{t}_{2}, \mathrm{Y}_{\mathrm{P}}$ and their standard errors $\mathrm{s}_{\mathrm{C}}, \mathrm{s}_{\mathrm{E}}, \mathrm{s}_{\mathrm{M}}, \mathrm{s}_{\mathrm{kE}}, \mathrm{s}_{\mathrm{kL}}, \mathrm{s}_{1}, \mathrm{~s}_{2}$, and $\mathrm{s}_{\mathrm{P}}$.

This modeling approach allows one to decompose and to quantify the pattern of each Y-kinetic by the use of two slopes $\left(\mathrm{k}_{\mathrm{E}}\right.$ and $\left.\mathrm{k}_{\mathrm{L}}\right)$, two times $\left(\mathrm{t}_{1}\right.$ and $\left.\mathrm{t}_{2}\right)$, one duration $\left(\mathrm{Y}_{\mathrm{P}}\right)$, two levels $\left(\mathrm{Y}_{\mathrm{M}}\right.$ and $\left.\mathrm{Y}_{\mathrm{C}}\right)$, and one change $\left(\mathrm{Y}_{\mathrm{E}}\right)$.

Two sequential mixed models were fitted with Proc MIXED of SAS (1992) to determine the effects of parity and YOP on parameter estimates. The first model focuses on the effect of parity on the slope of regression:

$$
\left(\theta_{\mathrm{p}}\right)_{\mathrm{ijk}}=\mathrm{P}_{\mathrm{j}}+\mathrm{t}_{\mathrm{k}}+\mathrm{B}_{\mathrm{j}} \cdot \mathrm{YOP}+\mathrm{e}_{\mathrm{ijk}},
$$

where,

$$
\begin{aligned}
\left(\theta_{\mathrm{p}}\right)_{\mathrm{ijk}}= & \text { estimate of the parameter } \theta_{\mathrm{p}}=\left\{\mathrm{Y}_{\mathrm{C}}, \mathrm{Y}_{\mathrm{E}},\right. \\
& \left.\mathrm{Y}_{\mathrm{M}}, \mathrm{k}_{\mathrm{E}}, \mathrm{k}_{\mathrm{L}}, \mathrm{t}_{1}, \mathrm{t}_{2}, \mathrm{Y}_{\mathrm{P}}\right\} \text { for the Y-kinetic of } \\
& \text { treatment group } \mathrm{i} \text { in trial } \mathrm{k} \text { (various num- } \\
& \text { ber of treatment groups and trials ac- } \\
& \text { cording to Y-kinetic and parameter } \theta \mathrm{p}) \text { for } \\
& \text { parity group } \mathrm{j}(\mathrm{j}=1,2+), \\
\mathrm{P}_{\mathrm{j}}= & \text { fixed effect of parity group } \mathrm{j}, \\
\mathrm{t}_{\mathrm{k}}= & \text { random effect of trial } \mathrm{k}, \\
\mathrm{B}_{\mathrm{j}}= & \text { regression coefficient of } \theta_{\mathrm{p}} \text { on YOP for par- } \\
& \text { ity group } \mathrm{j}, \\
\mathrm{e}_{\mathrm{ijk}}= & \text { error term } \sim \mathrm{N}\left(0, \sigma^{2}{ }_{\mathrm{e}}\right) .
\end{aligned}
$$

As in model [1], a significant effect of $\mathrm{Bj}$ indicated that the slope of the linear regression of $\theta_{\mathrm{P}}$ on YOP was different from zero for at least one parity group. Therefore, a second model was fitted as follows:

$$
\left(\theta_{\mathrm{p}}\right)_{\mathrm{ijk}}=\mu+\mathrm{P}_{\mathrm{j}}+\mathrm{t}_{\mathrm{k}}+\left(\beta_{0}+\beta_{\mathrm{j}}\right) \cdot \mathrm{YOP}+\mathrm{e}_{\mathrm{ijk}},
$$

where symbols are as previously defined with the following changes:

$\mu=$ overall mean,

$\beta_{0}=$ overall regression coefficient of $\theta_{\mathrm{p}}$ on YOP,

$\beta_{\mathrm{j}}=$ deviation of regression coefficient of $\theta \mathrm{p}$ on YOP from the overall regression coefficient for parity group $\mathrm{j}$.
As in model [2], a significant $\beta \mathbf{j}$ effect indicated that the slope of $\theta p$ on YOP was different for parity groups.

To account for unequal accuracy of estimates, leastsquares means were weighted as follow: for parameter $\theta_{\mathrm{p}}$ with standard error $\mathrm{s}_{\mathrm{p}}, \mathrm{w}_{1}$ is defined as the inverse of the squared of $\mathrm{s}_{\theta \mathrm{p}}$, and $\overline{\mathrm{w}}$ as its mean value over available data. Thus, $\mathrm{w}_{2}=\mathrm{w}_{1} / \mathrm{w}$ was used as weight (StPierre, 2001). This statistical model was aimed at quantifying the variability of the pattern of Y-kinetics across YOP and parity.

Three levels of correlations between parameter estimates were examined for kinetics of DMI, EBW, RMY and MFY:

(1) Between parameter estimates of the same Y-kinetic within treatment group (e.g. $\mathrm{DMI}_{\mathrm{kE}}$ and $\mathrm{DMI}_{\mathrm{kL}}$ for the first treatment group of Johnson (1983)). These correlations straight out of NLIN were implied by the mathematical properties of model [4].

(2) Between parameter estimates of the same Y-kinetic across treatment groups (e.g., $\mathrm{EBW}_{\mathrm{C}}$ and $\mathrm{EBW}_{\mathrm{E}}$ ). These correlations provided information about the structural dependencies within the pattern of each Y-kinetic.

(3) Between parameter estimates between Y-kinetics across treatment groups (parameters can be equivalent, e.g. $\mathrm{DMI}_{\mathrm{M}}$ and $\mathrm{RMY}_{\mathrm{M}}$, or different, e.g. $\mathrm{DMI}_{\mathrm{kE}}$ and $\mathrm{RMY}_{\mathrm{kL}}$ ). These correlations provided information about the relationships between the patterns of different Y-kinetics.

Asymptotic correlations of level (1) are model-dependent and therefore not different between Y-kinetics. The sign of parameters $\mathrm{k}_{\mathrm{E}}$ (negative for EBW, positive for DMI, RMY, and MFY) and $\mathrm{k}_{\mathrm{L}}$ (positive for EBW, negative for DMI, RMY, and MFY) determine the sign of all correlations except that between $t_{1}$ and $t_{2}$. This latter correlation is always negative and induced by the structural constraint $t_{2} \geq t_{1}$. Non null correlations exist within stages (within linear segments): between $\mathrm{k}_{\mathrm{E}}$ and $t_{1}$ in early stage, between $t_{1}$ and $Y_{M}$ and between $Y_{M}$ and $t_{2}$ in middle stage, and between $t_{2}$ and $k_{L}$ in late stage. Correlations between parameters of different stage were approximately null (in particular between $\mathrm{k}_{\mathrm{E}}$ and $\mathrm{Y}_{\mathrm{M}}, \mathrm{Y}_{\mathrm{M}}$, and $\mathrm{k}_{\mathrm{L}}$, and $\mathrm{k}_{\mathrm{E}}$ and $\mathrm{k}_{\mathrm{L}}$ ).

These results justify the corrections made with covariance components for unbiased estimates of parameter $\mathrm{YE}[5 \mathrm{a}]$ and standard error of parameters $\mathrm{Y}_{\mathrm{E}}[5 \mathrm{~b}], \mathrm{Y}_{\mathrm{C}}$ [6b], and $\mathrm{Y}_{\mathrm{P}}[7 \mathrm{~b}]$.

Correlations of levels (2) and (3) were all calculated within parity groups and within allocation systems A, $\mathrm{F}$, and R. Only correlations with the same sign and an absolute value greater than 0.5 in each parity group and allocation system were retained. Correlations within Ykinetic between parameters $\mathrm{Y}_{\mathrm{P}}$ and $\mathrm{Y}_{\mathrm{t} 2}$ and between 
parameters $\mathrm{Y}_{\mathrm{kE}}$ and $\mathrm{Y}_{\mathrm{E}}$ were removed since they were implied by construction ([6a] and [7a]). Finally the conditions were matched for two couples of parameters within the EBW-kinetic and four couples of parameters between kinetics of DMI, RMY and MFY. These six correlations by parity group and allocation system are presented in Table 6.

The following five couples of parameters $\left(\theta_{\mathrm{Y}}, \theta_{\mathrm{X}}\right)$ were retained for further analysis: (a) $\left(\mathrm{EBW}_{\mathrm{E}}, \mathrm{EBW}_{\mathrm{C}}\right)$, (b) $\left(\mathrm{RMY}_{\mathrm{M}}, \mathrm{DMI}_{\mathrm{M}}\right)(\mathrm{c})\left(\mathrm{RMY}_{\mathrm{kL}}, \mathrm{DMI}_{\mathrm{kL}}\right),(\mathrm{d})\left(\mathrm{MFY}_{\mathrm{M}}, \mathrm{RMY}_{\mathrm{M}}\right)$, and (e) $\left(\mathrm{MFY}_{\mathrm{kL}}, \mathrm{RMY}_{\mathrm{kL}}\right)$. Four sequential mixed models were fitted with Proc MIXED of SAS (1992) to determine the effect of parameter $\theta_{\mathrm{X}}$ on $\theta_{\mathrm{Y}}$ within parity. The first model focuses on the effect of parity on the slope of the regression.

$$
\left(\theta_{\mathrm{Y}}\right)_{\mathrm{ijk}}=\mathrm{P}_{\mathrm{j}}+\mathrm{t}_{\mathrm{k}}+\mathrm{B}_{\mathrm{j}} \cdot\left(\theta_{\mathrm{X}}\right)_{\mathrm{ijk}}+\mathrm{e}_{\mathrm{ijk}},
$$

where,

$$
\begin{aligned}
\left.\theta_{\mathrm{Y}}\right)_{\mathrm{ijk}}= & \text { estimate of the parameter } \theta_{\mathrm{Y}}=\left\{\mathrm{Y}_{\mathrm{C}}, \mathrm{Y}_{\mathrm{E}},\right. \\
& \left.\mathrm{Y}_{\mathrm{M}}, \mathrm{k}_{\mathrm{E}}, \mathrm{k}_{\mathrm{L}}, \mathrm{t}_{1}, \mathrm{t}_{2}, \mathrm{Y}_{\mathrm{P}}\right\} \text { for the } \mathrm{Y} \text {-kinetic of } \\
& \text { treatment group } \mathrm{i} \text { in trial } \mathrm{k} \text { (various num- } \\
& \text { ber of treatment groups and trial ac- } \\
& \text { cording to couple of parameters }\left(\theta_{\mathrm{Y}}, \theta_{\mathrm{X}}\right) \\
& \text { and } \mathrm{Y} \text {-kinetic) for parity group } \mathrm{j}(\mathrm{j}=1,2+), \\
\mathrm{P}_{\mathrm{j}}= & \text { fixed effect of parity group } \mathrm{j}, \\
\mathrm{t}_{\mathrm{k}}= & \text { random effect of trial } \mathrm{k} ; \\
\mathrm{B}_{\mathrm{j}}= & \text { regression coefficient of } \theta_{\mathrm{Y}} \text { on } \theta_{\mathrm{X}} \text { for parity } \\
& \text { group } \mathrm{j} ; \\
\left(\theta_{\mathrm{X}}\right)_{\mathrm{ijk}}= & \text { estimate of the parameter } \theta_{\mathrm{Y}}=\left\{\mathrm{Y}_{\mathrm{C}}, \mathrm{Y}_{\mathrm{E}},\right. \\
& \left.\mathrm{Y}_{\mathrm{M}}, \mathrm{k}_{\mathrm{E}}, \mathrm{k}_{\mathrm{L}}, \mathrm{t}_{1}, \mathrm{t}_{2}, \mathrm{Y}_{\mathrm{P}}\right\} \text { for the } \mathrm{Y}-\mathrm{kinetic} \text { of } \\
& \text { treatment group i for parity group j, } \\
\mathrm{e}_{\mathrm{ijk}}= & \text { error term } \sim \mathrm{N}\left(0, \sigma^{2}{ }_{\mathrm{e}}\right) .
\end{aligned}
$$

As in model [1] and [5], a significant effect of Bj indicated that the slope of the linear regression of $\theta_{\mathrm{Y}}$ on $\theta_{\mathrm{X}}$ was different from zero for at least one parity group. Therefore, a second model was fitted as follows:

$$
\left(\theta_{\mathrm{Y}}\right)_{\mathrm{ijk}}=\mu+\mathrm{P}_{\mathrm{j}}+\mathrm{t}_{\mathrm{k}}+\left(\beta_{0}+\beta_{\mathrm{j}}\right) \cdot\left(\theta_{\mathrm{X}}\right)_{\mathrm{ijk}}+\mathrm{e}_{\mathrm{ijk}},
$$

where symbols are as previously defined with the following changes:

$$
\begin{aligned}
\mu= & \text { overall mean, } \\
\beta_{0}= & \text { overall regression coefficient of } \theta_{\mathrm{Y}} \text { on } \theta_{\mathrm{X}} ; \\
\beta_{\mathrm{j}}= & \text { deviation of regression coefficient of } \theta_{\mathrm{Y}} \text { on } \\
& \theta_{\mathrm{X}} \text { from the overall regression coefficient } \\
& \text { for parity group } \mathrm{j} .
\end{aligned}
$$

As in model [2] and [6], a significant $\beta \mathrm{j}$ effect indicated that the slope of $\theta_{\mathrm{Y}}$ on $\theta_{\mathrm{X}}$ was different for parity groups. If not significant, a third model was fitted as follows:

$$
\left(\theta_{\mathrm{Y}}\right)_{\mathrm{ijk}}=\mu+\mathrm{P}_{\mathrm{j}}+\mathrm{t}_{\mathrm{k}}+\beta_{0} \cdot\left(\theta_{\mathrm{X}}\right)_{\mathrm{ijk}}+\mathrm{e}_{\mathrm{ijk}},
$$

where symbols are as previously defined.

A significant $P_{j}$ effect indicated that the intercept of the regression of $\theta_{\mathrm{Y}}$ on $\theta_{\mathrm{X}}$ was different for parity groups. If not significant, a fourth model was fitted as follows:

$$
\left(\theta_{\mathrm{Y}}\right)_{\mathrm{ijk}}=\mu+\mathrm{t}_{\mathrm{k}}+\beta_{0} \cdot\left(\theta_{\mathrm{X}}\right)_{\mathrm{ijk}}+\mathrm{e}_{\mathrm{ijk}},
$$

where symbols are as previously defined.

To account for unequal accuracies of estimates, leastsquares were weighted as follow: for parameters $\theta_{\mathrm{X}}$ and $\theta_{\mathrm{Y}}$ with respective standard errors $\mathrm{s}_{\mathrm{X}}$ and $\mathrm{s}_{\mathrm{Y}}, \mathrm{w}_{1}$ is defined as the inverse of the product $\mathrm{s}_{\mathrm{X}} \cdot \mathrm{s}_{\mathrm{Y}}$, and $\overline{\mathrm{w}}$ as its mean value over available data. Thus, $\mathrm{w}_{2}=\mathrm{w}_{1} \sqrt{\mathrm{w}}$ was used as weight (St-Pierre, 2001). By this way, both error on $\theta_{\mathrm{X}}$ and $\theta_{\mathrm{Y}}$ were used to estimate the regression coefficients.

These four models were aimed at quantifying the relationships between:

(a) the loss of EBW in early lactation and the EBW at calving,

(b) the plateau values of RMY and DMI in middle stage of lactation,

(c) the slopes of decrease of RMY and DMI in late stage of lactation,

(d) the plateau values of MFY and RMY in middle stage of lactation,

(e) the slopes of decrease of MFY and RMY in late stage of lactation.

The choice of independent (Y) vs dependent variable (X) was set in the sense of prediction of performances. Dependent variables were thus, either state at calving $\left(\mathrm{EBW}_{\mathrm{C}}\right)$ for prediction of $\mathrm{EBW}$ loss, characteristics of intake pattern $\left(\mathrm{DMI}_{\mathrm{M}}\right.$ and $\mathrm{DMI}_{\mathrm{kL}}$ ) for prediction of equivalent characteristics of RMY, or characteristics of milk yield pattern $\left(\mathrm{RMY}_{\mathrm{M}}\right.$ and $\mathrm{RMY}_{\mathrm{kL}}$ ) for prediction of equivalent characteristics of MFY pattern.

In statistical models [1], [2], [8], [9], [10], [11], [12], and [13], trials were considered as blocks and their effect was incorporated as random intercept. When significant, random slopes (interaction of trial by dependent variable) were incorporated in the reduced models [10], [11], [12], and [13]. This methodology takes into account the fact that observations within a given trial have more in common that observations across trials (St-Pierre, 2001).

\section{RESULTS}

\section{Database}

Diets. Table 2 describes the average chemical composition of diets fed to the 140 treatment groups. The 
Table 2. Chemical composition of diets (DM basis).

\begin{tabular}{lrrrrrr}
\hline Item & $\mathrm{n}_{\mathrm{A}}{ }^{1}$ & $\mathrm{n}_{\mathrm{T}}{ }^{2}$ & Mean & $\mathrm{CV}(\%)$ & Minimum & Maximum \\
\hline DM, \% & 25 & 92 & 57.5 & 37.1 & 27.2 & 93.4 \\
Ash, \% & 17 & 65 & 7.4 & 23.1 & 5.0 & 11.2 \\
Phosphorus, \% & 8 & 33 & 0.5 & 21.7 & 0.3 & 0.7 \\
Calcium, \% & 8 & 33 & 0.8 & 13.3 & 0.8 & 0.9 \\
OM, \% & 17 & 65 & 92.6 & 1.8 & 88.8 & 95.0 \\
Digestible OM, \% & 3 & 11 & 64.2 & 8.6 & 58.6 & 75.5 \\
CP, \% & 26 & 102 & 16.0 & 12.0 & 10.1 & 20.5 \\
Digestible CP, \% & 6 & 17 & 12.1 & 15.0 & 10.4 & 16.2 \\
Ether extract, \% & 18 & 71 & 4.0 & 31.0 & 2.0 & 7.3 \\
Crude fiber, \% & 17 & 63 & 18.3 & 26.5 & 3.4 & 32.2 \\
ADF, \% & 10 & 45 & 22.9 & 12.0 & 18.1 & 27.5 \\
Acid detergent lignin, \% & 2 & 11 & 5.1 & 10.4 & 4.5 & 5.7 \\
NDF, \% & 6 & 24 & 35.3 & 6.6 & 31.2 & 39.6 \\
Gross energy, Mcal/kg & 5 & 15 & 4.5 & 2.7 & 4.2 & 4.6 \\
Digestible energy, Mcal/kg & 3 & 6 & 3.2 & 6.3 & 2.9 & 3.4 \\
Metabolizable energy, Mcal/kg & 24 & 84 & 2.7 & 10.1 & 1.5 & 3.0 \\
NE, Mcal/kg & 9 & 28 & 1.6 & 17.2 & 0.9 & 2.0 \\
\hline
\end{tabular}

${ }^{1}$ Number of articles providing item chemical content data

${ }^{2}$ Number of treatment groups including item chemical content data.

availability of data was variable amongst articles. The major sources of variability appeared to be associated with DM, ash, phosphorus, ether extract, and crude fiber content (Coefficient of variation greater than $20 \%$ ). Metabolizable energy and CP contents, ranging from 1.5 to $3.0 \mathrm{Mcal} / \mathrm{kg} \mathrm{DM}$ and from 10.1 to $20.5 \%$ reflect experimental designs investigated.

A subset of 94 treatment groups were fed $\mathrm{CO}$ and $\mathrm{FO}$ separately, which ranged respectively from $17.9 \%$ to $75.9 \%$ and from $24.1 \%$ to $82.1 \%$ (DM basis) over wk 1 to 8 of lactation. A subset of 42 treatment groups were fed a TMR, including 4 treatment groups in DePeters et al. (1989) for which animals were fed both a TMR and FO at $13.7 \%$ or $25.9 \%$ of the total DMI. A subset of 4 treatment groups were only fed FO ad libitum (Mohrenweiser and Donker, 1968).

Feeding systems. A summary of feeding systems used across the 140 treatment groups is given in Table 3. From 1970 to 1999, TMR were only fed ad libitum.
Restricted allowances of FO or $\mathrm{CO}$ were used before 1984. Fitted or ad libitum programs of feeding FO or CO were investigated from 1965 to 1999 . Figure 3 shows the average fractions of diet fed A, F, and R according to the decade the article was published. The major part of DMI was mainly fed in a restricted way before 1970 $(>50 \% \mathrm{DMI})$ and was primarily fed ad libitum after 1980 (from 53\% to 100\% DMI amongst treatment groups). Before 1980, the underlying research was aimed at measuring the quantitative effects of intake on lactational performance (Table 1). Since 1980, ad libitum systems have been used predominantly, reflecting practical on-farm conditions: qualitative effects, mainly that of feed type, were therefore studied. Thus, data gathered across treatment groups were highly unbalanced with respect to feeding system.

Treatment group outcomes. Table 4 provides weighted least squares means of Y[1-8] by parity group (models [1] and [2]). Except for MFC and MPC, the

Table 3. Feeding systems applied for the 140 treatments.

\begin{tabular}{|c|c|c|c|c|c|c|}
\hline \multicolumn{3}{|c|}{ Diet } & \multicolumn{3}{|c|}{$\mathrm{n}^{1}$} & \multirow[b]{2}{*}{$\mathrm{YOP}^{3}$} \\
\hline $\mathrm{FO}^{2}$ & $\mathrm{CO}^{2}$ & TMR & Multiparous & Primiparous & Total & \\
\hline Ad libitum & & & 0 & 4 & 4 & 1968 \\
\hline Ad libitum & Ad libitum & & 5 & 1 & 6 & 1973-1997 \\
\hline Ad libitum & Fitted & & 31 & 13 & 44 & 1967-1993 \\
\hline Ad libitum & Restricted & & 4 & 5 & 9 & 1984 \\
\hline Fitted & Fitted & & 2 & 2 & 4 & 1992 \\
\hline Restricted & Mixed & & 8 & 0 & 8 & 1971-1983 \\
\hline Restricted & Fitted & & 10 & 1 & 11 & 1965-1979 \\
\hline Restricted & Restricted & & 0 & 12 & 12 & 1959-1975 \\
\hline & & Ad libitum & 29 & 13 & 42 & 1970-1999 \\
\hline Total & & & 89 & 51 & 140 & 1959-1999 \\
\hline
\end{tabular}

${ }^{1}$ Number of treatment groups.

${ }^{2} \mathrm{FO}=$ forage, $\mathrm{CO}=$ concentrate.

${ }^{3} \mathrm{YOP}=$ year of publication. 
Table 4. Weighted least squares means and significance of effects of parity and year of publication on average dependant variables over the first 8 weeks of lactation.

\begin{tabular}{|c|c|c|c|c|c|c|c|c|c|}
\hline \multirow{3}{*}{$\begin{array}{l}\text { Dependent } \\
\text { variable }^{2}\end{array}$} & \multirow{2}{*}{\multicolumn{3}{|c|}{ Multiparous }} & \multirow{2}{*}{\multicolumn{3}{|c|}{ Primiparous }} & \multicolumn{3}{|c|}{ Effect of $\mathrm{YOP}^{1}$} \\
\hline & & & & & & & \multicolumn{2}{|c|}{ Within parity ${ }^{6}$} & \multirow[b]{2}{*}{$P$ value ${ }^{7}$} \\
\hline & $\mathrm{n}^{3}$ & $\mathrm{LSM}^{4}$ & SEM $^{5}$ & $\mathrm{n}$ & LSM & SEM & Multiparous & Primiparous & \\
\hline DMI, kg/d & 83 & $16.79^{\mathrm{a}}$ & 0.28 & 44 & $13.51^{\mathrm{b}}$ & 0.34 & $0.19^{\mathrm{c}}$ & $0.08^{d}$ & $* * *$ \\
\hline FO DMI, $\mathrm{kg} / \mathrm{d}$ & 56 & $7.40^{\mathrm{a}}$ & 0.58 & 33 & $6.13^{\mathrm{b}}$ & 0.67 & & & NS \\
\hline CO DMI, kg/d & 54 & $9.10^{\mathrm{a}}$ & 0.48 & 27 & $7.09^{\mathrm{b}}$ & 0.66 & & & NS \\
\hline TMR DMI, $\mathrm{kg} / \mathrm{d}^{8}$ & 29 & $17.34^{\mathrm{a}}$ & 0.45 & 13 & $14.67^{\mathrm{b}}$ & 0.59 & 0.29 & 0.11 & $* * *$ \\
\hline MEI, Mcal/d & 64 & $42.61^{\mathrm{a}}$ & 1.10 & 32 & $34.66^{\mathrm{b}}$ & 1.39 & 0.59 & 0.41 & $* * *$ \\
\hline $\mathrm{RMY}, \mathrm{kg} / \mathrm{d}$ & 81 & $30.15^{\mathrm{a}}$ & 0.55 & 39 & $22.41^{\mathrm{b}}$ & 0.67 & $0.52^{\mathrm{c}}$ & $0.30^{\mathrm{d}}$ & $* * *$ \\
\hline FCM, kg/d & 53 & $28.06^{\mathrm{a}}$ & 0.58 & 25 & $20.89^{b}$ & 0.71 & 0.37 & 0.38 & $* * *$ \\
\hline MFY, g/d & 45 & $1111^{\mathrm{a}}$ & 29 & 20 & $878^{\mathrm{b}}$ & 34 & 10 & 9 & $* *$ \\
\hline MFC, $\mathrm{g} / \mathrm{kg}^{9}$ & 73 & 37.80 & 0.77 & 30 & 39.15 & 0.89 & & & NS \\
\hline MPY, g/d & 32 & $853^{\mathrm{a}}$ & 34 & 9 & $609^{\mathrm{b}}$ & 41 & 10 & 10 & $* *$ \\
\hline $\mathrm{MPC}, \mathrm{g} / \mathrm{kg}$ & 54 & 31.64 & 0.59 & 13 & 31.31 & 0.66 & & & NS \\
\hline MLY, $\mathrm{g} / \mathrm{d}$ & 3 & $(1149)^{10}$ & $(2)$ & 3 & (919) & $(160)$ & & & $\mathrm{ND}^{11}$ \\
\hline $\mathrm{MLC}, \mathrm{g} / \mathrm{kg}^{8}$ & 13 & 48.93 & 0.39 & 5 & 49.30 & 0.43 & -0.13 & 0.08 & $*$ \\
\hline $\mathrm{BW}, \mathrm{kg}$ & 89 & $578.7^{\mathrm{a}}$ & 4.9 & 50 & $503.0^{\mathrm{b}}$ & 5.8 & 2.3 & 1.2 & $* * *$ \\
\hline EBW, kg & 83 & $513.6^{\mathrm{a}}$ & 4.9 & 44 & $445.8^{\mathrm{b}}$ & 5.9 & 1.4 & 1.0 & $*$ \\
\hline
\end{tabular}

${ }^{\mathrm{a}, \mathrm{b}}$ Least squares means within row with different superscripts differ $(P<0.05)$.

${ }^{\mathrm{c}, \mathrm{d}}$ Estimates of regression slope within row with different superscripts differ $(P<0.05)$.

${ }^{1} \mathrm{YOP}=$ year of publication.

${ }^{2} \mathrm{FO} \mathrm{DMI}=$ forage DMI, CO DMI = concentrate DMI, MEI = metabolizable energy intake, $\mathrm{RMY}=$ raw milk yield, $\mathrm{MFY}=$ milk fat yield, $\mathrm{MFC}=$ milk fat content, $\mathrm{MPY}=$ milk protein yield, $\mathrm{MPC}=$ milk protein content, $\mathrm{MLY}=$ milk lactose yield, $\mathrm{MLC}=$ milk lactose content, $\mathrm{EBW}=$ empty BW.

${ }^{3}$ Number of treatment groups by parity group.

${ }^{4}$ Weighted least squares mean of mixed model of dependent variable on YOP including fixed effect of parity and random effect of trial (see model [1]).

${ }^{5}$ Standard error of the least squares mean.

${ }^{6}$ Estimate of regression slope of dependent variable on YOP.

${ }^{7}$ Regression slope of dependent variable on YOP different from zero for at least one parity group.

${ }^{8}$ Random effect of trial not significant $(P>0.1)$.

${ }^{9}$ Least squares means not significantly different at the level of $6 \%$.

${ }^{10}$ Group mean and standard error.

${ }^{11}$ Not determined.

${ }^{\mathrm{NS}} P>0.1$.

$* P \leq 0.05$.

$* * P \leq 0.01$.

$* * * P \leq 0.001$.

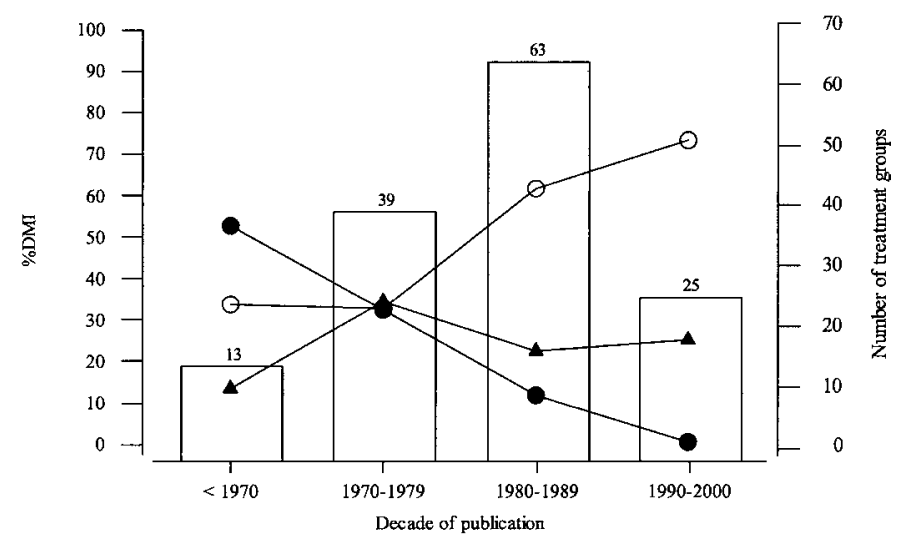

Figure 3. Number of treatment groups (histogram) and average fraction of diet (\%DMI) fed, ad libitum $(\bigcirc)$, fitted to current performances $(\boldsymbol{\Lambda})$ or restricted $(\bullet)$ according to decade of article publication. fixed effect of parity was significant $(P<0.01)$. Multi had higher DMI (+ 3.3 kg/d), higher FO DMI (+ $1.3 \mathrm{~kg} /$ d), higher CO DMI (+2.0 kg/d), higher TMDMI (+ 2.7 $\mathrm{kg} / \mathrm{d}$ ), and higher MEI (+8.0 Mcal/d) than Primi. Multi had higher RMY (+ $7.7 \mathrm{~kg} / \mathrm{d})$, higher FCM $(+7.1 \mathrm{~kg} / \mathrm{d})$ than Primi. The higher level of RMY for Multi was associated with significantly higher levels of MFY (+ $233 \mathrm{~g} / \mathrm{d})$ and MPY (+ $244 \mathrm{~g} / \mathrm{d})$. Multi were heavier than Primi (BW: $+75.7 \mathrm{~kg}$, EBW: $+67.8 \mathrm{~kg}$ ). The effect of the YOP was found to be significant $(P<0.01)$ for at least one parity group for all variables except $\mathrm{MFC}$, MPC, FO DMI, and CO DMI. Significant effects of the YOP were different between parity groups for variables DMI and RMY.

\section{Kinetic Patterns}

Table 5 provides weighted least squares means and standard errors of least squares means of parameter 
Table 5. Weighted least squares means and significance of effects of parity and year of publication on parameter estimates for kinetics of DMI, Raw milk yield (RMY), Milk fat yield (MFY), and Empty BW (EBW).

\begin{tabular}{|c|c|c|c|c|c|c|c|c|c|c|}
\hline \multirow[b]{3}{*}{ Kinetic } & \multirow[b]{3}{*}{ Parameter $^{2}$} & \multirow{2}{*}{\multicolumn{3}{|c|}{ Multiparous }} & \multirow{2}{*}{\multicolumn{3}{|c|}{ Primiparous }} & \multicolumn{3}{|c|}{ Effect of $\mathrm{YOP}^{1}$} \\
\hline & & & & & & & & \multicolumn{2}{|c|}{ Within parity ${ }^{6}$} & \multirow[b]{2}{*}{$P$-value ${ }^{7}$} \\
\hline & & $n^{3}$ & $\mathrm{LSM}^{4}$ & $\mathrm{SEM}^{5}$ & $\mathrm{n}$ & LSM & SEM & Multiparous & Primiparous & \\
\hline \multirow[t]{8}{*}{ DMI } & $\mathrm{DMI}_{\mathrm{C}}$ & 75 & $12.45^{\mathrm{a}}$ & 0.49 & 37 & $10.01^{\mathrm{b}}$ & 0.56 & $0.16^{\mathrm{c}}$ & $0.02^{\mathrm{d}}$ & $*$ \\
\hline & $\mathrm{k}_{\mathrm{E}}$ & 81 & $1.16^{\mathrm{a}}$ & 0.15 & 41 & $0.94^{\mathrm{b}}$ & 0.16 & & & NS \\
\hline & $t_{1}$ & 81 & 5.8 & 0.4 & 41 & 6.7 & 0.5 & 0.0 & 0.2 & $*$ \\
\hline & $\mathrm{DMI}_{\mathrm{E}}$ & 75 & 6.41 & 0.46 & 37 & 5.72 & 0.52 & 0.05 & 0.12 & * \\
\hline & $\mathrm{DMI}_{\mathrm{M}}$ & 83 & $18.63^{\mathrm{a}}$ & 0.41 & 41 & $15.69^{b}$ & 0.33 & 0.22 & 0.13 & $* * *$ \\
\hline & $t_{2}$ & 62 & $12.6^{\mathrm{b}}$ & 1.4 & 36 & $26.4^{\mathrm{a}}$ & 1.7 & & & NS \\
\hline & $\mathrm{k}_{\mathrm{L}}$ & 53 & $-0.17^{\mathrm{b}}$ & 0.01 & 31 & $-0.08^{a}$ & 0.02 & & & NS \\
\hline & $\mathrm{DMI}_{\mathrm{P}}$ & & $6.9^{\mathrm{b}}$ & 1.2 & 36 & $19.8^{\mathrm{a}}$ & 1.5 & & & NS \\
\hline \multirow[t]{8}{*}{ EBW } & $\mathrm{EBW}_{\mathrm{C}}$ & 70 & $557.1^{\mathrm{a}}$ & 7.0 & 36 & $476.9^{b}$ & 8.6 & 2.4 & 1.6 & $* *$ \\
\hline & & 81 & -10.2 & 1.2 & 42 & -8.0 & 1.5 & -0.2 & -0.3 & $*$ \\
\hline & & 81 & $4.4^{\mathrm{a}}$ & 0.2 & 42 & $3.3^{\mathrm{b}}$ & 0.3 & & & NS \\
\hline & $\mathrm{EBW}_{\mathrm{E}}$ & 70 & $-56.2^{\mathrm{b}}$ & 4.5 & 36 & $-42.0^{\mathrm{a}}$ & 5.4 & -0.9 & -0.7 & $\dagger$ \\
\hline & $\mathrm{EBW}_{\mathrm{M}}$ & 83 & $501.4^{\mathrm{a}}$ & 5.2 & 44 & $431.6^{\mathrm{b}}$ & 4.3 & 1.6 & 1.3 & $* *$ \\
\hline & $t_{2}$ & 72 & 12.0 & 1.2 & 38 & 13.3 & 1.4 & -0.2 & -0.2 & $\dagger$ \\
\hline & $\mathrm{k}_{\mathrm{L}}$ & 68 & 2.4 & 0.2 & 38 & 2.5 & 0.2 & & & NS \\
\hline & $\mathrm{EBW}_{\mathrm{P}}$ & 60 & 8.7 & 0.9 & 34 & 8.8 & 1.1 & & & NS \\
\hline \multirow[t]{8}{*}{ RMY } & $\mathrm{RMY}_{\mathrm{C}}$ & 64 & $22.10^{\mathrm{a}}$ & 0.94 & 30 & $15.07^{\mathrm{b}}$ & 1.07 & 0.33 & 0.17 & * \\
\hline & & 75 & 2.62 & 0.39 & 36 & 2.31 & 0.41 & & & NS \\
\hline & & 75 & 3.9 & 0.2 & 36 & 4.4 & 0.3 & & & NS \\
\hline & $\mathrm{RMY}_{\mathrm{E}}$ & 64 & $10.20^{\mathrm{a}}$ & 1.00 & 30 & $8.29^{b}$ & 1.18 & & & NS \\
\hline & $\mathrm{RMY}_{\mathrm{M}}$ & 81 & $31.67^{\mathrm{a}}$ & 0.66 & 38 & $23.74^{\mathrm{b}}$ & 0.77 & 0.42 & 0.36 & $* * *$ \\
\hline & & 75 & $7.5^{\mathrm{b}}$ & 0.5 & 36 & $9.0^{\mathrm{a}}$ & 0.7 & 0.0 & 0.3 & $*$ \\
\hline & & 78 & $-0.56^{\mathrm{b}}$ & 0.02 & 37 & $-0.29^{\mathrm{a}}$ & 0.03 & & & NS \\
\hline & $\mathrm{RMY}_{\mathrm{P}}$ & 66 & $4.1^{\mathrm{b}}$ & 0.4 & 26 & $8.1^{\mathrm{a}}$ & 0.7 & $0.1^{\mathrm{d}}$ & $0.3^{\mathrm{c}}$ & $*$ \\
\hline \multirow[t]{8}{*}{$\mathrm{MFY}^{8}$} & $\mathrm{MFY}_{\mathrm{C}}$ & 2 & $\mathrm{ND}^{9}$ & ND & 2 & ND & ND & & & ND \\
\hline & $\mathrm{k}_{\mathrm{E}}$ & 13 & 11 & 3 & 10 & 10 & 4 & & & NS \\
\hline & & 13 & 4.4 & 1.6 & 10 & 3.4 & 1.7 & & & NS \\
\hline & $\mathrm{MFY}_{\mathrm{E}}$ & 2 & & ND & 2 & ND & ND & & & ND \\
\hline & $\mathrm{MFY}_{\mathrm{M}}$ & 45 & $1201^{\mathrm{a}}$ & 38 & 20 & $900^{\mathrm{b}}$ & 42 & 0 & 15 & $\dagger$ \\
\hline & & 25 & $6.6^{\mathrm{b}}$ & 1.0 & 15 & $9.8^{\mathrm{a}}$ & 1.2 & & & NS \\
\hline & $\mathrm{k}_{\mathrm{L}}$ & 45 & $-18^{\mathrm{b}}$ & 1 & 20 & $-11^{\mathrm{a}}$ & 1 & & & NS \\
\hline & $\mathrm{MFY}_{\mathrm{P}}$ & 8 & $3.9^{\mathrm{b}}$ & 0.9 & 8 & $4.2^{\mathrm{a}}$ & 1.2 & & & NS \\
\hline \multicolumn{11}{|c|}{$\begin{array}{l}\text { a,b Least squares means within row with different superscripts differ }(P<0.05) \\
{ }^{1} \mathrm{YOP}=\text { year of publication. }\end{array}$} \\
\hline \multicolumn{11}{|c|}{$\begin{array}{l}{ }^{2} \mathrm{Y}_{\mathrm{C}}=\mathrm{Y} \text { at calving, } \mathrm{k}_{\mathrm{E}} \text { and } \mathrm{k}_{\mathrm{L}}=\text { slope of } \mathrm{Y} \text { in early and late lactation, } \mathrm{t}_{1} \text { and } \mathrm{t}_{2}=\text { lower and upper bounds } \\
\text { of middle stage, } \mathrm{Y}_{\mathrm{E}}=\text { variation in } \mathrm{Y} \text { in early stage, } \mathrm{Y}_{\mathrm{M}}=\text { plateau value of } \mathrm{Y} \text { in middle stage, } \mathrm{Y}_{\mathrm{P}}=\text { duration } \\
\text { of middle stage. }\end{array}$} \\
\hline \multicolumn{11}{|c|}{${ }^{3}$ Number of treatment groups by parity. } \\
\hline \multicolumn{11}{|c|}{$\begin{array}{l}{ }^{4} \text { Weighted least squares mean of mixed model of parameter on YOP including fixed effect of parity and } \\
\text { random effect of trial (see model [8]). }\end{array}$} \\
\hline \multicolumn{11}{|c|}{${ }^{5}$ Standard error of the least squares mean. } \\
\hline \multicolumn{11}{|c|}{${ }^{6}$ Estimate of regression slope of parameter on YOP. } \\
\hline \multirow{2}{*}{\multicolumn{11}{|c|}{$\begin{array}{l}{ }^{7} \text { Regression slope of parameter on YOP different fro } \\
{ }^{8} \text { Random intercept nonsignificant for all parameters }\end{array}$}} \\
\hline & & nons & gnificant $\mathrm{fc}$ & r all $\mathrm{p}$ & ram & $\operatorname{ters}(P>$ & $0.1)$. & & & \\
\hline \\
\hline${ }^{\mathrm{NS}} P>$ & 0.1. & & & & & & & & & \\
\hline$\dagger P \leq C$ & & & & & & & & & & \\
\hline$* P \leq C$ & & & & & & & & & & \\
\hline$* * P \leq$ & 01. & & & & & & & & & \\
\hline & 001. & & & & & & & & & \\
\hline
\end{tabular}

estimates by parity group for variables DMI, RMY, EBW, and MFY (models [8] and [9]). Values cited in the following text are weighted least squares means \pm standard error within parity group.
Dry matter intake. Goodness-of-fit was not different between parity groups, and the overall average RMSE was $0.48 \pm 0.24 \mathrm{~kg} / \mathrm{d}$. The distribution of the $124 \mathrm{R}^{2}$ calculated is given in Figure $4\left(\mathrm{R}^{2}=91.3 \pm 7.9 \%\right)$. 


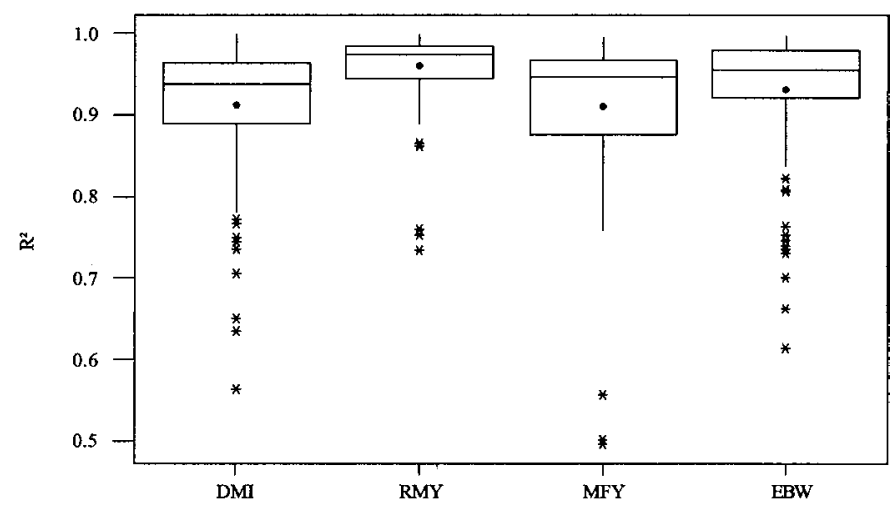

Figure 4. Box plot of $R^{2}$ of model of Grossman et al. (1999) fitted to treatment group kinetics of DMI, raw milk yield (RMY), milk fat yield (MFY), and empty BW (EBW). Bottom and top edges of the box are located at the sample 25th and 75th percentiles; center horizontal line is at the sample median; central filled circle is at the sample mean; asterisks are values more extreme than three interquartile ranges (distance between the 25 th and 75 th sample percentiles).

From 1959 to 1999, the annual increase in $\mathrm{DMI}_{\mathrm{M}}$ was significant $(P<0.001$; Multi: $+0.22 \mathrm{~kg} / \mathrm{yr}$, Primi: +0.13 $\mathrm{kg} / \mathrm{yr}$ ). This increase was obtained with a higher level of intake at calving mainly for Multi (Multi: $\mathrm{DMI}_{\mathrm{C}}$ : + $0.16 \mathrm{~kg} / \mathrm{yr}$, Primi: $\mathrm{DMI}_{\mathrm{C}}$ : $+0.02 \mathrm{~kg} / \mathrm{yr}$ ) and a higher increase in intake in early lactation mainly for Primi (Multi: $\mathrm{DMI}_{\mathrm{E}}$ : + $0.05 \mathrm{~kg} / \mathrm{yr}$, Primi: $\mathrm{DMI}_{\mathrm{E}}:+0.12 \mathrm{~kg} / \mathrm{yr}$ ). No significant effect of the YOP on the $\mathrm{k}_{\mathrm{E}}$ was found. Nevertheless, the annual increase in $t_{1}$ was significant $(P<0.05)$ and nonnull for Primi $(+0.2 \mathrm{wk} / \mathrm{yr})$. Effect of YOP was not significant for parameters $t_{2}, k_{L}$, and $\mathrm{DMI}_{\mathrm{P}}$.

Weighted least squares means of parameters were different between parity group except for $t_{1}(6.3 \pm 0.5$ wk for pooled parity groups $)$ and $\mathrm{DMI}_{\mathrm{E}}(6.18 \pm 0.48 \mathrm{~kg}$ for pooled parity groups). Primi had a lower level of DMI at calving than Multi $\left(\mathrm{DMI}_{\mathrm{C}}:-2.44 \mathrm{~kg}\right)$ and a lower slope of increase in early stage (Primi: $\mathrm{k}_{\mathrm{E}}=0.94 \pm 0.16$ $\mathrm{kg} / \mathrm{wk}$, Multi: $\left.\mathrm{k}_{\mathrm{E}}=1.16 \pm 0.15 \mathrm{~kg} / \mathrm{wk}\right)$ which induced a lower level in middle stage (Primi: $\mathrm{DMI}_{\mathrm{M}}=15.69 \pm$ $0.33 \mathrm{~kg}$, Multi: $\mathrm{DMI}_{\mathrm{M}}=18.63 \pm 0.41 \mathrm{~kg}$ ). It should be mentioned that the range of $\mathrm{k}_{\mathrm{E}}$ estimates was higher for restricted schemes of feeding than for others. The end of the plateau stage was reached significantly later by Primi $\left(\mathrm{t}_{2}=26.4 \pm 1.7 \mathrm{wk}, \mathrm{DMI}_{\mathrm{P}}=19.8 \pm 1.5 \mathrm{wk}\right)$ than Multi $\left(\mathrm{t}_{2}=12.6 \pm 1.4 \mathrm{wk}, \mathrm{DMI}_{\mathrm{P}}=6.9 \pm 1.2 \mathrm{wk}\right)$.

No correlation was retained within the kinetic of DMI. Only kinetics of the ad libitum allocation system could express animal requirements. Patterns of the fitted and restricted allocation systems are mainly determined by experimental designs.

Empty body weight. Goodness-of-fit was not different between parity groups, and the overall average
RMSE was $4.2 \pm 1.8 \mathrm{~kg}$. The distribution of the $128 \mathrm{R}^{2}$ calculated is given in Figure $4\left(\mathrm{R}^{2}=93.1 \pm 7.4 \%\right)$.

From 1959 to 1999, the annual increases in $\mathrm{EBW}_{\mathrm{M}}$ and $\mathrm{EBW}_{\mathrm{C}}$ were significant $(P<0.01)$ and not different between parity groups $\left(\mathrm{EBW}_{\mathrm{M}}:+1.5 \mathrm{~kg} / \mathrm{yr}\right.$ and $\mathrm{EBW}_{\mathrm{C}}$ : $+2.1 \mathrm{~kg} / \mathrm{yr}$ for pooled parity groups). The effect of YOP was higher for $\mathrm{EBW}_{\mathrm{C}}$ than for $\mathrm{EBW}_{\mathrm{M}}$ because of the associated reduction in $\mathrm{k}_{\mathrm{E}}$ while $\mathrm{t}_{1}$ was not affected. Thus, Primi and Multi were heavier at calving and their total loss of EBW in early stage was greater $\left(\mathrm{EBW}_{\mathrm{E}}\right.$ : $0.8 \mathrm{~kg} / \mathrm{yr}$ for pooled parity groups). Time $\mathrm{t}_{2}$ was also influenced by the YOP for both parity groups $\left(t_{2}:-0.2\right.$ wk/yr for pooled parity groups). No significant effect of the YOP on parameters $\mathrm{k}_{\mathrm{L}}$ and $\mathrm{EBW}_{\mathrm{P}}$ was detected.

Weighted least squares means of parameters were different between parity group except for the slopes $\mathrm{k}_{\mathrm{E}}$ and $\mathrm{k}_{\mathrm{L}}(-9.4 \pm 1.3 \mathrm{~kg} / \mathrm{wk}$ and $2.4 \pm 0.2 \mathrm{~kg} / \mathrm{wk}$ respectively for pooled parity groups) and for the time $t_{2}(12.4 \pm 1.3$ wk for pooled parity groups). Multi had a higher level of $\mathrm{EBW}_{\mathrm{C}}(+80.2 \mathrm{~kg})$ and a higher level of $\mathrm{EBW}_{\mathrm{M}}(+69.8$ $\mathrm{kg})$ induced by a greater $\mathrm{EBW}_{\mathrm{E}}$ in early stage $(-14.2$ $\mathrm{kg}$ ) achieved $1.1 \mathrm{wk}$ later than Primi (Primi: $\mathrm{t}_{1}=3.3 \pm$ 0.3 , Multi: $t_{1}=4.4 \pm 0.2$ ). Duration of the middle stage (plateau at minimum EBW before regrowth) was not different between parity groups $\left(\mathrm{EBW}_{\mathrm{P}}=8.7 \pm 1.0 \mathrm{wk}\right)$.

The only correlations between parameters within Ykinetics deemed coherent within parity and allocation system (Table 6) were found between $\mathrm{EBW}_{\mathrm{E}}$ and $\mathrm{EBW}_{\mathrm{C}}$, and between $\mathrm{EBW}_{\mathrm{M}}$ and $\mathrm{EBW}_{\mathrm{C}}$ (respectively $\rho=-0.73$ and $\rho=+0.89$ for pooled data). These relationships stressed the primary influence of animal size at calving on the early decrease of BW.

The relationship between $\mathrm{EBW}_{\mathrm{E}}$ and $\mathrm{EBW}_{\mathrm{C}}$ is presented in Figure 5. Weighting factors applied were globally homogeneous across treatment groups. Slopes of $\mathrm{EBW}_{\mathrm{E}}$ on $\mathrm{EBW}_{\mathrm{C}}$ were different from zero within parity $(P<0.001$, model [10] $)$. The difference in the slopes between parity groups was not significant $(P=0.688$, model [11]) and the difference in the intercepts between parity group was significant $(P<0.001$, model [12]).

The regression equation proposed was obtained from [12]:

$$
\mathrm{EBW}_{\mathrm{E}}(\mathrm{kg})=(145.9+\Delta)-0.39 \mathrm{EBW}_{\mathrm{C}}(\mathrm{kg}) .
$$

where $\Delta=0.0$ for Primi and $\Delta=19.6$ for Multi. This model was fitted for 104 treatment groups spread across 34 trials, and had a residual error of $9.0 \mathrm{~kg}$ (residual standard error of random intercept: $13.0 \mathrm{~kg}$ ). Regression coefficient of model [14] gives an estimate of the within-trial effect of animal weight at calving on early depletion.

Raw milk yield. Goodness-of-fit was not different between parity groups and the overall average RMSE 


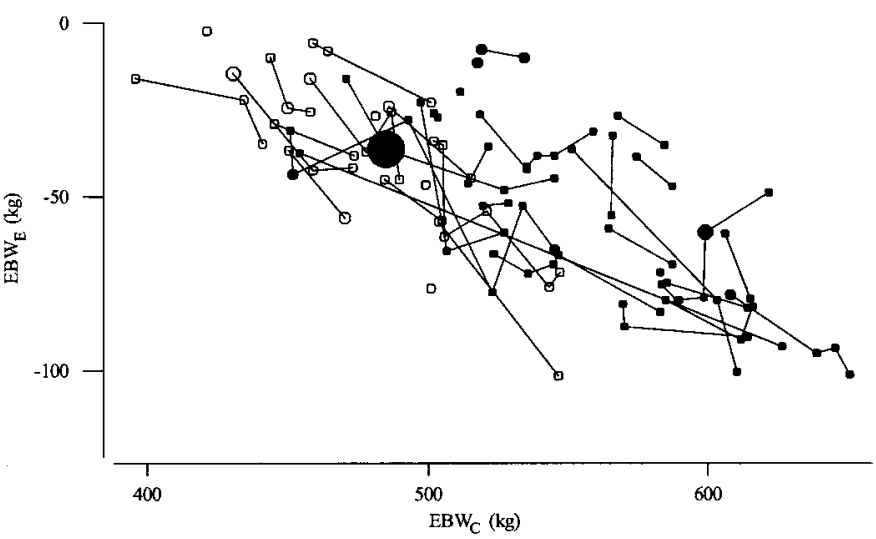

Figure 5. Plot of $\mathrm{EBW}_{\mathrm{E}}$ (total loss of empty BW in early lactation) on $\mathrm{EBW}_{\mathrm{C}}$ (empty BW at calving) for multiparous $(-$ ) and primiparous (○). Data are linked by trial and sized with respect to weight used in weighted least-squares analysis.

was $0.66 \pm 0.34 \mathrm{~kg} / \mathrm{d}$. The distribution of the $119 \mathrm{R}^{2}$ calculated is given in Figure $4\left(\mathrm{R}^{2}=96.1 \pm 4.5 \%\right)$. These results were better than those obtained with the alternative form of the lactation model of Wood (Wood, 1967) proposed by Dhanoa (Dhanoa, 1981) using the same dataset $\left(\mathrm{RMSE}=0.79 \pm 0.36 \mathrm{~kg} / \mathrm{d}, \mathrm{R}^{2}=93.8 \pm 6.9 \%\right)$.

From 1959 to 1999, the annual increases in $\mathrm{RMY}_{\mathrm{M}}$ and $\mathrm{RMY}_{\mathrm{C}}$ were significant $(P<0.05)$ and not different between parity groups $\left(\mathrm{RMY}_{\mathrm{M}}:+0.40 \mathrm{~kg} / \mathrm{yr}\right.$ and $\mathrm{RMY}_{\mathrm{C}}$ : $+0.28 \mathrm{~kg} / \mathrm{yr}$ for pooled parity groups). The effect of YOP was significant on $t_{2}$ and $\mathrm{RMY}_{\mathrm{P}}\left(\mathrm{t}_{2}:+0.1 \mathrm{wk} / \mathrm{yr}\right.$ and $\mathrm{DMI}_{\mathrm{P}}:+0.2 \mathrm{wk} / \mathrm{yr}$ for pooled parity groups). No significant effect of the YOP was detected on other parameters.

Weighted least squares means of parameters were different between parity group except for $\mathrm{k}_{\mathrm{E}}$ and $\mathrm{t}_{1}\left(\mathrm{k}_{\mathrm{E}}\right.$ $=2.52 \pm 0.40 \mathrm{~kg} / \mathrm{wk}$ and $\mathrm{t}_{1}=4.1 \pm 0.2 \mathrm{wk}$ for pooled

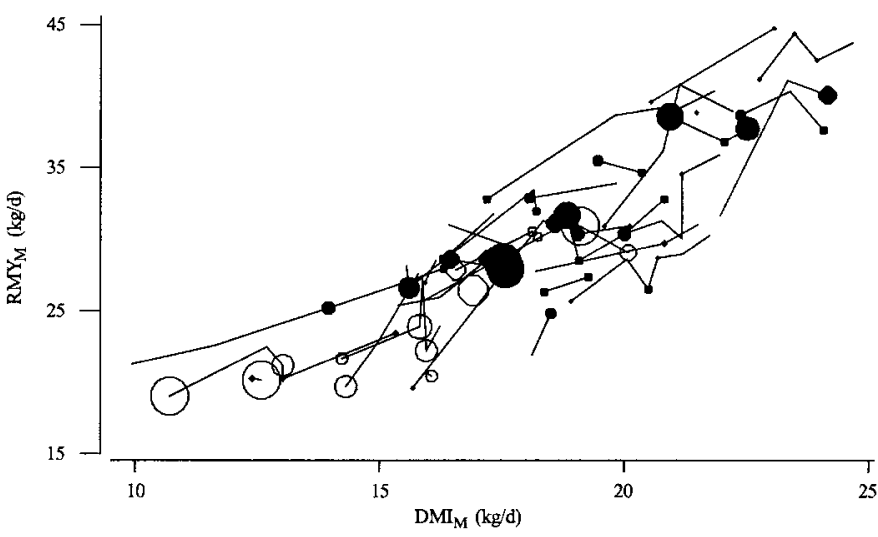

Figure 6. Plot of $\mathrm{RMY}_{\mathrm{M}}$ (plateau value of raw milk yield in middle stage of lactation) on $\mathrm{DMI}_{\mathrm{M}}$ (plateau value of DMI in middle stage of lactation) for multiparous $(\bullet)$ and primiparous $(\bigcirc)$. Data are linked by trial and sized with respect to weight used in weighted least squares-analysis.

parity groups). Multi had a higher level of $\mathrm{RMY}_{\mathrm{C}}(+$ $7.03 \mathrm{~kg})$ and a higher level of $\mathrm{RMY}_{\mathrm{M}}(+7.93 \mathrm{~kg})$. Multi had a shorter persistency (Primi: $\mathrm{RMY}_{\mathrm{P}}=8.1 \pm 0.7 \mathrm{wk}$, Multi: $\left.\mathrm{RMY}_{\mathrm{P}}=4.1 \pm 0.4 \mathrm{wk}\right)$ obtained with an earlier time $\mathrm{t}_{2}$ (Primi: $\mathrm{t}_{2}=7.5 \pm 0.5 \mathrm{wk}$, Multi: $\mathrm{t}_{2}=9.0 \pm 0.7$ wk). The weekly rate of decrease in RMY in late stage was significantly higher for Primi $\left(\mathrm{k}_{\mathrm{L}}=-0.29 \pm 0.03\right.$ $\mathrm{kg} / \mathrm{wk})$ than Multi $\left(\mathrm{k}_{\mathrm{L}}=-0.56 \pm 0.02 \mathrm{~kg} / \mathrm{wk}\right)$.

No correlation was retained within the kinetic of RMY. Nevertheless, the plateau value and the slope of decrease in RMY during late stage were found to be correlated with equivalent parameters for DMI. The relationship between $\mathrm{RMY}_{\mathrm{M}}$ and $\mathrm{DMI}_{\mathrm{M}}$ is presented in Figure 6. Since the accuracy of parameter estimates was not equivalent across treatment groups, the weighting factors applied were heterogeneous. The dif-

Table 6. Correlations between parameter estimates within and between kinetics (only correlations of same sign and with absolute value greater than 0.5 for both parity groups and allocation systems are presented).

\begin{tabular}{|c|c|c|c|c|c|c|c|c|c|c|c|c|}
\hline & & & \multicolumn{4}{|c|}{ Parity } & \multicolumn{6}{|c|}{ Allocation system ${ }^{1}$} \\
\hline & \multicolumn{2}{|c|}{ Couple of parameters ${ }^{2}$} & $\mathrm{n}^{3}$ & $\mathrm{r}$ & $\mathrm{n}$ & $\mathrm{r}$ & $\mathrm{n}$ & $\mathrm{r}$ & $\mathrm{n}$ & $\mathrm{r}$ & $\mathrm{n}$ & $\mathrm{r}$ \\
\hline Within $\mathrm{EBW}^{4}$ & $\begin{array}{l}\mathrm{EBW}_{\mathrm{E}} \\
\mathrm{EBW}_{\mathrm{M}}\end{array}$ & $\begin{array}{l}\mathrm{EBW}_{\mathrm{C}} \\
\mathrm{EBW}_{\mathrm{C}}\end{array}$ & $\begin{array}{l}70 \\
70\end{array}$ & $\begin{array}{r}-0.69 \\
0.81\end{array}$ & $\begin{array}{l}36 \\
36\end{array}$ & $\begin{array}{r}-0.77 \\
0.79\end{array}$ & $\begin{array}{l}58 \\
58\end{array}$ & $\begin{array}{r}-0.76 \\
0.91\end{array}$ & $\begin{array}{l}30 \\
30\end{array}$ & $\begin{array}{r}-0.60 \\
0.83\end{array}$ & $\begin{array}{l}18 \\
18\end{array}$ & $\begin{array}{r}-0.51 \\
0.79\end{array}$ \\
\hline Between kinetics ${ }^{5}$ & $\begin{array}{l}\mathrm{DMI}_{\mathrm{kL}} \\
\mathrm{DMI}_{\mathrm{M}} \\
\mathrm{RMY}_{\mathrm{kL}} \\
\mathrm{RMY}_{\mathrm{M}}\end{array}$ & $\begin{array}{l}\mathrm{RMY}_{\mathrm{kL}} \\
\mathrm{RMY}_{\mathrm{M}} \\
\mathrm{MFY}_{\mathrm{kL}} \\
\mathrm{MFY}_{\mathrm{M}}\end{array}$ & $\begin{array}{l}47 \\
75 \\
43 \\
45\end{array}$ & $\begin{array}{l}0.85 \\
0.80 \\
0.54 \\
0.77\end{array}$ & $\begin{array}{l}21 \\
29 \\
19 \\
20\end{array}$ & $\begin{array}{l}0.52 \\
0.84 \\
0.74 \\
0.82\end{array}$ & $\begin{array}{l}25 \\
57 \\
20 \\
23\end{array}$ & $\begin{array}{l}0.60 \\
0.82 \\
0.51 \\
0.78\end{array}$ & $\begin{array}{l}34 \\
35 \\
33 \\
33\end{array}$ & $\begin{array}{l}0.74 \\
0.85 \\
0.85 \\
0.84\end{array}$ & $\begin{array}{r}9 \\
12 \\
9 \\
9\end{array}$ & $\begin{array}{l}0.83 \\
0.58 \\
0.51 \\
0.61\end{array}$ \\
\hline
\end{tabular}

\footnotetext{
${ }^{1}$ Allocation system of the major part of the diet.

${ }^{2} \mathrm{Y}_{\mathrm{E}}=$ variation in $\mathrm{Y}$ in early stage, $\mathrm{Y}_{\mathrm{C}}=\mathrm{Y}$ at calving, $\mathrm{Y}_{\mathrm{M}}=$ plateau value of $\mathrm{Y}$ in middle stage, $\mathrm{k}_{\mathrm{L}}=$ slope of $\mathrm{Y}$ in late stage.

${ }^{3}$ Number of treatment groups involved by parity group or allocation system.

${ }^{4} \mathrm{EBW}=$ empty BW.

${ }^{5} \mathrm{RMY}=$ raw milk yield, $\mathrm{MFY}=$ milk fat yield.
} 


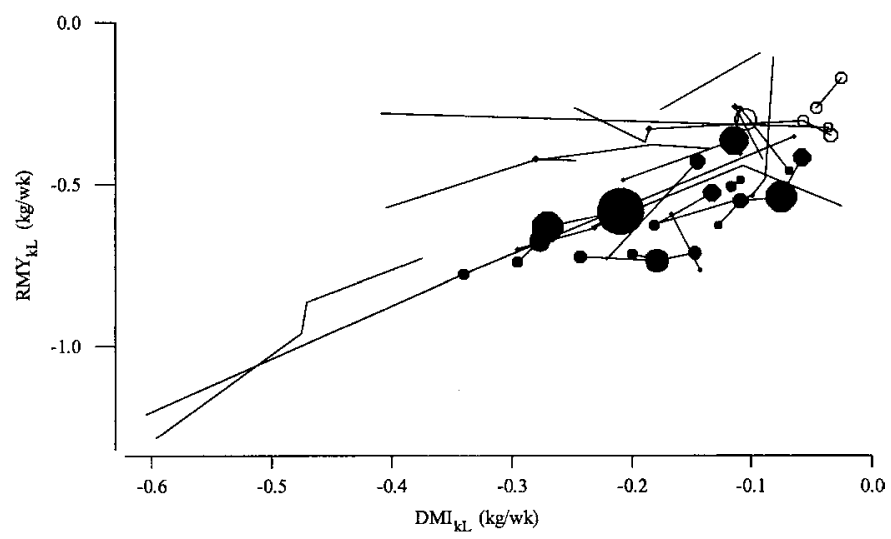

Figure 7. Plot of $\mathrm{RMY}_{\mathrm{kL}}$ (slope of weekly decrease in raw milk yield in late stage of lactation) on $\mathrm{DMI}_{\mathrm{kL}}$ (slope of weekly decrease in DMI in late stage of lactation) for multiparous (-) and primiparous $(\bigcirc)$. Data are linked by trial and sized with respect to weight used in weighted least-squares analysis.

ference in the slopes of $\mathrm{RMY}_{\mathrm{M}}$ on $\mathrm{DMI}_{\mathrm{M}}$ between parity group was significant $(P<0.001$, model [11]). The difference in intercepts between parity groups was significant $(P<0.01$, model [11]). Random effects on slope, on intercept, and random interaction between random slope and intercept were found to be significant (respectively $P=0.068, P=0.066$, and $P=0.071$ ) and were therefore incorporated in retained model [10].

The regression equation for Multi is:

$$
\operatorname{RMY}_{\mathrm{M}}(\mathrm{kg} / \mathrm{d})=(3.43)+1.498 \mathrm{DMI}_{\mathrm{M}}(\mathrm{kg} / \mathrm{d}),
$$

and the equation for Primi is:

$$
\operatorname{RMY}_{\mathrm{M}}(\mathrm{kg} / \mathrm{d})=(19.16)+0.374 \mathrm{DMI}_{\mathrm{M}}(\mathrm{kg} / \mathrm{d}) .
$$

This model was fitted for 119 treatment groups spread across 31 trials and had a residual error of $0.32 \mathrm{~kg}$ (residual standard error of random intercept: $13.7 \mathrm{~kg}$ ). Regression coefficients of models [15] and [16] give an estimate of the within-trial increase in plateau value of milk yield associated with an increase in plateau value of DMI (about 1.5 and $0.4 \mathrm{~kg}$ RMY $/ \mathrm{kg}$ DMI for Multi and Primi respectively).

The relationship between $R M Y_{k L}$ and $\mathrm{DMI}_{\mathrm{kL}}$ is presented in Figure 7. Since the accuracy of parameter estimates was not equivalent across treatment groups, the weighting factors applied were heterogeneous. The difference in the slopes of $\mathrm{RMY}_{\mathrm{kL}}$ on $\mathrm{DMI}_{\mathrm{kL}}$ between parity group was significant $(P<0.001$, model (11]) but only the slope within the Multi group was different from zero $(P<0.001$, model [101]). The difference in the intercepts of $\mathrm{RMY}_{\mathrm{kL}}$ on $\mathrm{DMI}_{\mathrm{kL}}$ between parity group was also significant $(P<0.05$, model [11]).
The regression equation for Multi is (model [10]):

$$
\begin{aligned}
& \mathrm{RMY}_{\mathrm{kL}}(\mathrm{kg} / \mathrm{wk})=(-0.366) \\
& +1.239 \mathrm{DMI}_{\mathrm{kL}}(\mathrm{kg} / \mathrm{wk})
\end{aligned}
$$

and the equation for Primi is (model [10]):

$$
\begin{aligned}
& \mathrm{RMY}_{\mathrm{kL}}(\mathrm{kg} / \mathrm{wk})=(-0.273) \\
& +0.191 \mathrm{DMI}_{\mathrm{kL}}(\mathrm{kg} / \mathrm{wk})
\end{aligned}
$$

This model was fitted for 68 treatment groups spread across 21 trials and had a residual error of $0.06 \mathrm{~kg} / \mathrm{wk}$ (residual standard error of random intercept: $0.06 \mathrm{~kg}$ / wk). The models [17] and [18] allow direct quantification of the incidence of the kinetic of intake on the kinetic of milk yield in late stage of lactation. This result emphasizes the potential effect that feeding management has on milk yield in late lactation.

Milk fat yield. Goodness-of-fit was significantly better for Primi (20 treatment groups, RMSE $=27 \pm 10 \mathrm{~g} /$ d) than Multi (45 treatment groups, RMSE $=40 \pm 18$ $\mathrm{g} / \mathrm{d})$. The distribution of the $65 \mathrm{R}^{2}$ calculated is given in Figure $4\left(R^{2}=91.4 \pm 9.0 \%\right)$.

The effect of YOP was significant only for parameter $\mathrm{MFY}_{\mathrm{M}}(P<0.1)$ and only for Primi $\left(\mathrm{MFY}_{\mathrm{M}}\right.$ : $\left.+15 \mathrm{~g} / \mathrm{yr}\right)$. A valid detection of an early stage with increasing MFY $\left(t_{1} \neq t_{0}\right)$ was only detected for 23 treatment groups, and a valid estimate of $\mathrm{MFY}_{\mathrm{E}}$ in early stage was only calculated for 4 treatment groups. Due to the number of parameter estimates, models [8] and [9] were not applied to parameters $\mathrm{MFY}_{\mathrm{C}}$, and $\mathrm{MFY}_{\mathrm{E}}$.

Weighted least squares means of parameters were different between parity groups for all parameters except $\mathrm{k}_{\mathrm{E}}$ and $\mathrm{t}_{1}\left(\mathrm{k}_{\mathrm{E}}=11 \pm 3 \mathrm{~g} / \mathrm{wk}\right.$ and $\mathrm{t}_{1}=4.0 \pm 1.6 \mathrm{wk}$ for pooled parity groups). Multi had a higher level of $\mathrm{MFY}_{\mathrm{M}}(+301 \mathrm{~g} / \mathrm{d})$, an earlier time $\mathrm{t}_{2}(-3.2 \mathrm{wk})$, and a higher slope of decrease in late stage (Primi: $\mathrm{k}_{\mathrm{L}}=-11$ $\pm 1 \mathrm{~g} / \mathrm{wk}$, Multi: $\left.\mathrm{k}_{\mathrm{L}}=-18 \pm 1 \mathrm{~g} / \mathrm{wk}\right)$. No correlation was retained within the kinetic of MFY. Nevertheless, the plateau value and the slope of decrease in MFY during late stage were found to be correlated with equivalent parameters for RMY.

The relationship between $\mathrm{MFY}_{\mathrm{M}}$ and $\mathrm{RMY}_{\mathrm{M}}$ is presented in Figure 8. Since the accuracy of parameter estimates was not equivalent across treatment groups, the weighting factors applied were heterogeneous. The difference in slopes between parity groups was significant $(P<0.001$, model [11]), and the difference in intercepts between parity groups was also significant $(P<$ 0.05 , model [11]). Random effects on slope, on intercept, and random interaction between random slope and intercept were found to be significant $(P=0.058, P=$ 0.049 , and $P=0.057$, respectively) and were therefore incorporated in model [10]. 


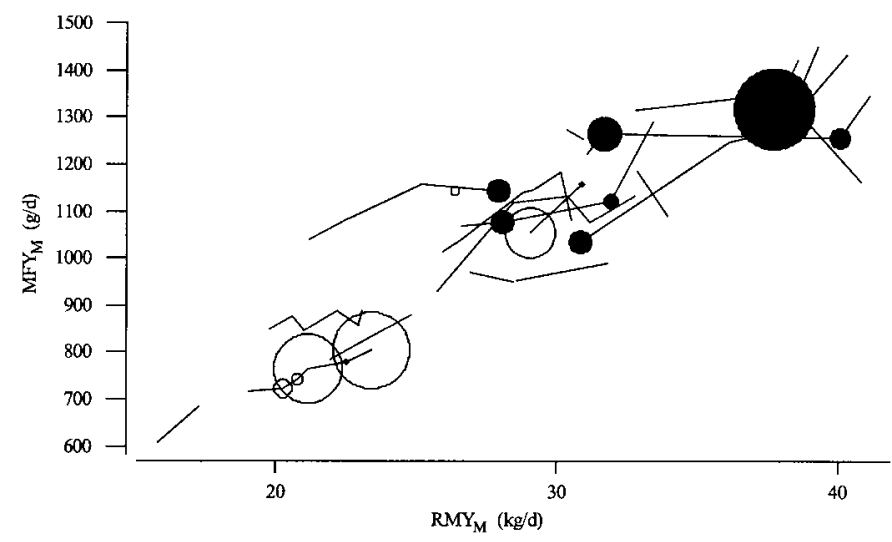

Figure 8. Plot of $\mathrm{MFY}_{\mathrm{M}}$ (plateau value of milk fat yield in middle stage of lactation) on $\mathrm{RMY}_{\mathrm{M}}$ (plateau value of raw milk yield in middle stage of lactation) for multiparous $(\bullet)$ and primiparous $(\bigcirc)$. Data are linked by trial and sized with respect to weight used in weighted least-squares analysis.

The regression equation for Multi is:

$$
\operatorname{MFY}_{\mathrm{M}}(\mathrm{g} / \mathrm{d})=(803)+11.2 \mathrm{RMY}_{\mathrm{M}}(\mathrm{kg} / \mathrm{d}),
$$

and the equation for Primi is:

$$
\operatorname{MFY}_{M}(\mathrm{~g} / \mathrm{d})=(-86)+39.8 \mathrm{RMY}_{\mathrm{M}}(\mathrm{kg} / \mathrm{d}) .
$$

This model was fitted for 65 treatment groups spread across 18 trials and has a residual error of $6 \mathrm{~g} / \mathrm{d}$ (residual standard error of random intercept: $16 \mathrm{~g} / \mathrm{d}$ ). Predictions of models [19] and [20] are consistent with observations of peak yield of milk and fat of Schutz et al. (1990) and Stanton et al. (1992).

The relationship between $\mathrm{MFY}_{\mathrm{kL}}$ and $\mathrm{RMY}_{\mathrm{kL}}$ is presented in Figure 9. Since the accuracy of parameter

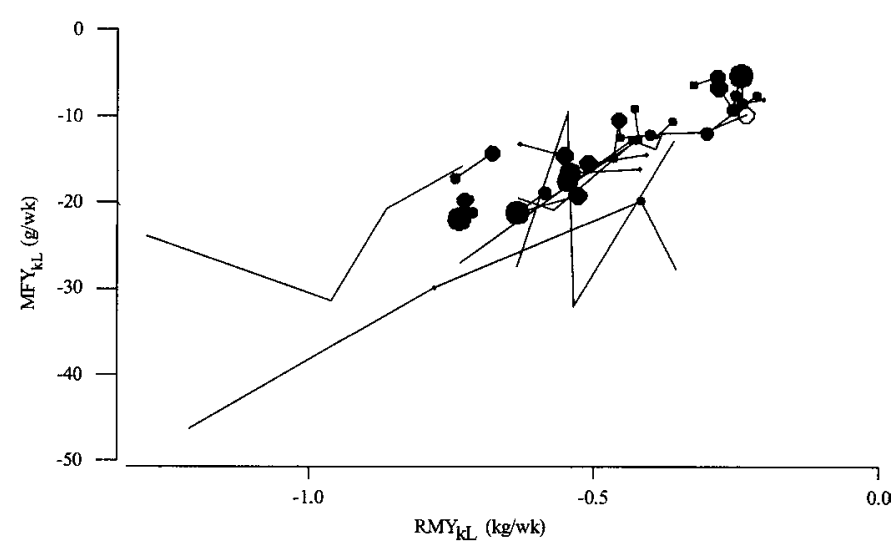

Figure 9. Plot of $\mathrm{MFY}_{\mathrm{kL}}$ (slope of weekly decrease in milk fat yield in late stage of lactation) on $\mathrm{RMY}_{\mathrm{kL}}$ (slope of weekly decrease in raw milk yield in late stage of lactation) for multiparous $(0)$ and primiparous $(\bigcirc)$. Data are linked by trial and sized with respect to weight used in weighted least-squares analysis. estimates was not equivalent across treatment groups, the weighting factors applied were heterogeneous. The difference in slopes between parity groups was not significant $(P=0.283$, model [10]), and the difference in intercepts between parity groups was also not significant $(P=0.088$, model [12]). The regression equation proposed for both parity groups is (model [13]):

$$
\begin{aligned}
& \operatorname{MFY}_{\mathrm{kL}}(\mathrm{g} / \mathrm{wk})=(-1.82) \\
& +27.65 \mathrm{RMY}_{\mathrm{kL}}(\mathrm{kg} / \mathrm{wk})
\end{aligned}
$$

This model was fitted for 62 treatment groups spread across 18 trials and has a residual error of $1.8 \mathrm{~g} / \mathrm{wk}$ (residual standard error of random intercept: $3.0 \mathrm{~g} / \mathrm{wk}$ ). This model gives a direct quantification of dynamic yield of milk and fat during the late stage of lactation.

\section{DISCUSSION}

The challenge of metaanalysis is to identify the general features of a system through the study of pooled data from different origins. This approach was selected to examine lactation kinetics.

Each kinetic collected in the database was recorded in a particular experimental context which can be defined by animal factors (breed, genotype, potential, parity, age, health, etc.), feed factors (composition, digestibility, particle size, energy value, etc.), environmental conditions (temperature, calving season, etc.), farm management (housing, feeding, milking, weighing, etc.), experimental design (allocation system, etc.), and analysis techniques (chemical composition of diet, milk constituents content, etc.). Not all these factors were defined in the different experiments used. Moreover, the criteria used to select these data, which were based on the availability of the three pieces of information (DMI, RMY, BW), induced a bias in the sample. The database was used as a collection of various kinetics rather than an experimental metadesign. Hence, our purpose was to quantify the variability of these kinetics between treatment groups. This overall variability includes the between-trial variability (random effect), associated with experimental conditions, and the withintrial variability, associated with experimental factors. Only parity as fixed effect was incorporated in statistical models to deal with this latter source of variability.

The majority of the trials were carried out on Holstein-Friesian cows, but animals differed in size, intake, and milk yield potential. Values of DMI, RMY, and EBW ranged in middle stage of lactation between 10.1 to $24.7 \mathrm{~kg}, 15.5$ to $44.4 \mathrm{~kg}$, and 320 to $573 \mathrm{~kg}$, respectively. The variability was mainly explained by parity and YOP effects. From 1969 to 1999, the $\mathrm{DMI}_{\mathrm{M}}$ increased by $6.6 \mathrm{~kg}$, while the RMY $\mathrm{R}_{\mathrm{M}}$ increased by 15.3 
$\mathrm{kg}$ and the $\mathrm{EBW}_{\mathrm{M}}$ increased by $51 \mathrm{~kg}$. The increase with time reflects genetic selection and improved management. The corresponding annual increase in 44-wk milk yield was of $165 \mathrm{~kg}$.

The correction of BW for gastrointestinal contents was aimed at calculating the unbiased changes in body reserves. Nevertheless, the correction factor of 4 was applied without taking into account the type of diet, especially the ratio of FO to CO. Several equations, already proposed to explain and predict the rumen volume, have been reviewed by Sauvant (1996) and provided very different estimations of rumen content for the same diet. If rumen load and therefore gut fill is more closely related to fiber or FO intake, as several data have suggested (Paquay et al., 1971), the $\mathrm{EBW}_{\mathrm{E}}$ would have been overestimated in the present model for higher yielding animals. Moreover, corrections were not made for uterine involution in early lactation, gravid uterus growth in late lactation, and udder growth in early lactation. Gier and Marion (1968) reported a decrease of $8.5 \mathrm{~kg}$ in BW due to uterine involution during the first $3 \mathrm{wk}$ of lactation. This could lead to an overestimation in the loss of body reserves in early lactation. In order to more precisely estimate the early depletion in BW due to mobilization, BW must be split into uterus weight, udder weight, total digestive tract weight, and EBW.

The model proposed by Grossman et al. (1999) summarizes the kinetics into main intersecting straight lines and, hence, into a vector of concrete parameters. We proposed to use this analytical approach on all kinetics of performance data during lactation. This allowed the quantification and the linking of patterns of intake, yield, and BW. In the case of milk yield, the overall goodness-of-fit was greater with this model than with the model of Wood-Dhanoa. Considering its goodness-of-fit, its use for each kind of kinetic, and the concrete signification of its five parameters, the model of Grossman could be a satisfying alternative tool for modeling the course of lactation.

The evolution in EBW was not found to be influenced by DMI, RMY or MFY in early lactation. The major effect that explained EBW loss was the level of EBW at calving (model [14]). This result agrees with the review of Broster and Broster (1984), who observed no clear buffering effect regarded as the "cow's ability to counter nutritional insults by withdrawal of body reserves to support milk production". This result needs to be validated in a context of severe under-nutrition in early lactation. Finally, the knowledge of the BCS at calving could probably improve the prediction of body reserve depletion. The evolution in RMY and in MFY exhibited very different shapes according to parity, especially according to the level of yield in midlactation and the slope of decrease in late lactation. These results are consistent with results of Schutz et al. (1990) and Stanton et al. (1992). In particular, the current data confirmed the well-known influence of parity on lactation kinetics. Models [15], [16], [19], and [20] allowed the prediction of plateau values of RMY and MFY according to DMI and RMY respectively, by parity. Models [17] and [21] focused on dynamic aspect of the lactation through the relationships between slopes of decrease in intake and milk yield, and milk and fat yield. The choice of DMI as a predictor for RMY is coherent with a "push" viewpoint of lactation (Mertens, 1996) for which milk secretion is considered as a consequence of energy intake. From the opposite "pull" viewpoint, intake is a response to requirements. Only mechanistic models could integrate regulation systems gathering together "push" and "pull" concepts.

\section{CONCLUSIONS}

This metaanalysis has highlighted the importance of three main types of effect in the dynamics of lactation: general scale relationship within the couple (intake, yield), incidence of animal size on mobilization of body reserves in early lactation, and effect of lower plane of nutrition on decreasing milk yield and associated decrease in fat yield in late lactation. This work has also opened up the possibility of building an empirical model of lactation kinetics by use of parameter vectors of the model proposed by Grossman (1999). Further trials should be included in the database to validate the regression models obtained.

\section{ACKNOWLEDGMENTS}

The authors thank Dr. P. Schmidely, Dr. V. Berthelot, and Dr. S. Robin for suggestions and assistance.

\section{REFERENCES}

Broster, W. H., and V. J. Broster. 1984. Reviews of the progress of dairy science: Long term effects of plane of nutrition on the performance of the dairy cow. J. Dairy Res. 51:149-196.

Broster, W. H., V. J. Broster, and T. Smith. 1969. Experiments on the nutrition of the dairy heifer. VIII. Effect on milk production of level of feeding at two stages of the lactation. J. Agric. Sci. 72:229-245.

Broster, W. H., V. J. Broster, T. Smith, and J. W. Siviter. 1975. Experiments on the nutrition of the dairy heifer. IX. Food utilization in lactation. J. Agric. Sci. 34:173-186.

Chilliard, Y., B. Rémond, J. Agabriel, J. Robelin, and R. Vérité. 1987. Variations du contenu digestif et des reserves corporelles au cours du cycle gestation-lactation. Bull. Tech. C.R.Z.V. Theix, INRA 70:117-131.

Cobby, J. M., and Y. L. P. Le Du. 1978. On fitting curves to lactation data. Anim. Prod. 26:127-133.

Cowan, E. D., J. Oliver, and R. C. Elliott. 1970. Complete diets for dairy cows. 1 . The health, reproductive performance, voluntary food intake and milk yield of cows fed with diets of different 
roughage content throughout lactation. Rhod. J. Agric. Res. $8: 15-22$.

Decaen, C., and J. Adda. 1970. Evolution de la sécrétion des acides gras des matières grasses du lait au cours de la lactation de la vache. Ann. Biol. Anim. Biochim. Biophys. 10:659-677.

Deluyker, H. A., R. H. Shumway, W. E. Wecker, A. S. Azari, and L. D. Weaver. 1990. Modeling daily milk yield in Holstein cows using time series analysis. J. Dairy Sci. 73:539-548.

DePeters, E. J., J. F. Medrano, and D. L. Bath. 1989. A nutritional evaluation of mixed winter cereals with vetch utilized as silage or hay. J. Dairy Sci. 72:3247-3254.

DePeters, E. J., N. E. Smith, and J. Acedo-Rico. 1985. Three or two times daily milking of older cows and first lactation cows for entire lactation. J. Dairy Sci. 68:123-132.

Dhanoa, M. S. 1981. A note on an alternative form of the lactation model of Wood. Anim. Prod. 32:349-351.

Dhanoa, M. S., and Y. L. P. Le Du. 1982. A partial adjustment model to describe the lactation curve of a dairy cow. Anim. Prod. $34: 243-247$.

Dijkstra, J., J. France, M. S. Dhanoa, J. A. Maas, M. D. Hanigan, A. J. Rook, and D. E. Beever. 1997. A model to describe growth patterns of the mammary gland during pregnancy and lactation. J. Dairy Sci. 80:2340-2354.

Donker, J. D., G. D. Marx, and C. W. Young. 1983. Feed intake and milk production from three rates of concentrate for cows bred to differ in size. J. Dairy Sci. 66:1337-1348.

Elston, D. A., C. A. Glasbey, and D. R. Neilson. 1989. Non-parametric lactation curves. Anim. Prod. 48:331-339.

Emmans, G. C., D. R. Neilson, and A. Gibson. 1983. A general description of dairy cow potential. Anim. Prod. 36:546.

Everson, R. A., N. A. Jorgensen, J. W. Crowley, E. L. Jensen, and G. P. Barrington. 1976. Input-output of dairy cows fed a complete ration of a constant or variable forage-to-grain ratio. J. Dairy Sci. 56:1776-1787.

Garnsworthy, P. C., and J. H. Topps. 1982. The effect of body condition of dairy cows at calving on their food intake and performance when given complete diet. Anim. Prod. 35:113-119.

Gier, H. T., and G. B. Marion. 1968. Uterus of the cow after parturition: involutional changes. Am. J. Vet. Res. 29:83-96.

Goodall, E. A., and D. Sprevak. 1984. A note on a stochastic model to describe the milk yield of a dairy cow. Anim. Prod. 38:133-136.

Goodall, E. A., and D. Sprevak. 1985. A Bayesian estimation of the lactation curve of a dairy cow. Anim. Prod. 40:189-193.

Grossman, M., and W. J. Koops. 1988. Multiphasic analysis of lactation curves in dairy cattle. J. Dairy Sci. 71:1598-1608.

Grossman, M., S. M. Hartz, and W. J. Koops. 1999. Persistency of lactation yield: A novel approach. J. Dairy Sci. 82:2192-2197.

Holter, J. B., H. H. Hayes, N. Kierstead, and J. Whitehouse. 1993. Protein-fat bypass supplement for lactating dairy cows. J. Dairy Sci. 76:1342-1352.

Holter, J. B., and H. H. Hayes. 1992. Weekly balancing crude protein in diets for Holstein cows throughout lactation using one versus two grain. J. Dairy Sci. 75:2473-2483.

Holter, J. B., C. K. Bozak, W. E. Hylton, and D. Coates. 1984. Reduced concentrate for Holstein first-calf heifers. J. Dairy Sci. 67:553559.

Holter, J. B., W. E. Hylton, C. B. Smith, and W. E. Urban. 1982. Reducing concentrate feeding for lactating dairy cows. J. Dairy Sci. 65:37-51.

Johnson, C. L. 1977. The effect of the plane and pattern of concentrate feeding on milk yield and composition in dairy cows. J. Agric. Sci. 88:79-84.

Johnson, C. L. 1979. The effect of level and frequency of concentrate feeding on the performance of dairy cows of different yield potential. J. Agric. Sci. 92:743-751.

Johnson, C. L. 1983. Influence of feeding pattern on the biological efficiency of high-yielding dairy cows. J. Agric. Sci. 100:191-199.

Kertz, A. F., L. F. Reutzel, and G. M. Thomson. 1991. Dry matter intake from parturition to midlactation. J. Dairy Sci. 74:22902295.

Koops, W. J., and M. Grossman. 1993. Multiphasic allometry. Growth Dev. Aging 57:183-192.
Krohn, C. C., T. Hvelplund, and P. E. Andersen. 1983. The effect on performance of different energy concentrations in complete rations for first lactation cows before and after calving. Livest. Prod. Sci. 10:223-237.

Kronfeld, D. S., S. Donoghue, K. Naylor, and C. A. Bradley. 1980. Metabolic effects of feeding protected tallow to dairy cows. J. Dairy Sci. 63:545-552.

Lahr, D. A., D. E. Otterby, D. G. Johnson, J. G. Linn, and R. G. Lundquist. 1983. Effects of moisture content of complete diets on feed intake and milk production by cows. J. Dairy Sci. 66:1891-1900.

Lodge, G. A., L. J. Fisher, and J. R. Lessard. 1975. Influence of prepartum feed intake on performance of cows fed ad libitum during lactation. J. Dairy Sci. 58:696-702.

Masselin, S., D. Sauvant, P. Chapoutot, and D. Milan. 1987. Les modèles d'ajustement des courbes de lactation. Ann. Zootech. 36:171-206.

Mertens, D. R. 1996. Methods in modelling feeding behaviour and intake in herbivores. Ann. Zootech. 45:153-164.

Mohrenweiser, H. W., and J. D. Donker. 1968. Forage evaluation. II. Productive response of first-calf Holstein heifers fed early-cut alfalfa hay as the only source of energy throughout a total lactation. J. Dairy Sci. 51:367-372.

Morant, S. V., and A. Gnanasakthy. 1989. A new approach to mathematical formulation of lactation curves. Anim. Prod. 49:151-162.

Neal, H. D. S. C., and J. H. M. Thornley. 1983. The lactation curve in cattle: a mathematical model of the mammary gland. J. Agric. Sci. (Camb.) 101:389-400.

Østergaard, V. 1979. Page 138 in Strategies for concentrate feeding to attain optimum feeding level in high yielding dairy cows. Beretning fra statens husdyrbrugs fors $\emptyset \mathrm{g} \mathrm{N}^{\circ} 482$. Dairy Sci. Abstr. 41:5710.

Ostersen, S., J. Foldager, and J. E. Hermansen. 1997. Effects of stage of lactation, milk protein genotype and body condition at calving on protein composition and renneting properties of bovine milk. J. Dairy Sci. 64:207-219.

Papajcsik, I. A., and J. Bodero. 1988. Modelling lactation curves of Friesian cows in a subtropical climate. Anim. Prod. 47:201-207.

Paquay, R., R. De Baere, and A. Lousse. 1971. Des variations du poids vif chez la bête bovine. Rev. Agric. 4:419-429.

Pinchasov, Y., A. Hasdai, S. Gordin, D. Katznelson, and R. Volcani. 1982. Performance of high-yielding dairy cows fed liquid whey. J. Dairy Sci. 65:28-36.

Posthumus, S. 1960. The determination of the protein content of milk by the colorimetric method. Neth. Milk Dairy J. 14:319-333.

Rémond, B., J. Robelin, and Y. Chilliard. 1988. Estimation de la teneur en lipids des vaches laitières Pie Noire. INRA Productions Animales 1:111-114.

Rook, A. J., J. France, and M. S. Dhanoa. 1993. On the mathematical description of lactation curves. J. Agric. Sci. 121:97-102.

Rook, J. A. F., and R. C. Campling. 1965. Effect of stage and number of lactation on the yield and composition of cow's milk. J. Dairy Res. 32:45-55.

Rook, J. A. F., and C. Line. 1961. The effect of the plane of energy nutrition of the cow on the secretion in milk of the constituents of the solids-not-fat fraction and on the concentrations of certain blood-plasma constituents. Brit. J. Nutr. 15:109.

Rowlands, G. J., S. Lucey, and A. M. Russel. 1982. A comparison of different models of the lactation curve in dairy cattle. Anim. Prod. 35:135-144.

Sauvant, D. 1996. A comparative evaluation of models of lactating ruminant. Ann. Zootech. 45:215-235.

SAS/STAT User's Guide. 1992. Version 6 Edition. SAS Institute Inc., Cary, NC.

Schneeberger, M. 1981. Inheritance of lactation curve in Swiss Brown cattle. J. Dairy Sci. 64:475-483.

Schutz, M. M., L. B. Hansen, G. R. Steuernagel, and A. L. Kuck. 1990. Variation of milk, fat, protein, and somatic cells for dairy cattle. J. Dairy Sci. 73:484-493.

Soder, K. L., and L. A. Holden. 1999. Dry matter intake and milk yield and composition of cows fed yeast prepartum and postpartum. J. Dairy Sci. 82:605-610. 
Somogyi, M. 1952. Notes on sugar determination. J. Biol. Chem. 195:19-23.

Stanton, T. L., L. R. Jones, R. W. Everett, and S. D Kachman. 1992. Estimating milk, fat, and protein lactation curves with a test day model. J. Dairy Sci. 75:1691-1700.

Staples, C. R., W. W. Thatcher, and J. H. Clark. 1990. Relationship between ovarian activity and energy status during early pospartum. J. Dairy Sci. 73:938-947.

St-Pierre, N. R. 2001. Invited review: integrating quantitative findings from multiple studies using mixed model methodology. J. Dairy Sci. 84:741-755.

Swanson, E. W., S. A. Hinton, and J. T. Miles. 1967. Full lactation response on restricted vs ad libitum roughage diets with liberal concentrate feeding. J. Dairy Sci. 50:1147-1152.

Taylor, W., and J. D. Leaver. 1984a. Systems of concentrate allocation for dairy cattle. 2. A comparison of two patterns of allocation for autumn-calving cows offered two qualities of grass silage $a d$ libitum. Anim. Prod. 39:325-333.

Taylor, W., and J. D. Leaver. 1984b. Systems of concentrate allocation for dairy cattle. 1. Comparison of three patterns of allocation for autumn-calving cows and heifers offered grass silage ad libitum. Anim. Prod. 39:315-324.

Tolkamp, B. J., R. J. Dewhurst, N. C. Friggens, I. Kyriazazkis, R. F. Veerkamp, and J. D. Oldham. 1998. Diet choice by dairy cows. 1. Selection of feed protein content during the first half of lactation. J. Dairy Sci. 81:2657-2669.

Udy, D. C. 1956. A rapid method for estimating total protein in milk. Nature 178:314.

Vérité, R., and M. Journet. 1977. Utilisation de tourteaux traités au formol par les vaches laitières. II. Effets sur la production laitière du traitement des tourteaux et du niveau d'apport azoté au début de la lactation. Ann. Zootech. (Paris) 26:183-205.

Wallace, L. R. 1959. Pages 196-203 in The nutrients requirement for milk production at successive stages of lactation. A study with identical twins. In XV Int. Dairy Congr., Vol. 1, London.

Wiktorsson, H. 1971. Studies on the effects of different levels of nutrition to dairy cows. Swedish J. Agric. Res. 1:83-103.

Wiktorsson, H. 1973. Feeding dairy cows during the first part of lactation. 1. Comparison of ad libitum versus restricted feeding of hay and concentrate. Swedish J. Agric. Res. 3:153-160.

Wohlt, J. E., and J. H. Clark. 1978. Nutritional value of urea versus preformed protein for ruminants. I. Lactation of dairy cows fed corn based diets containing supplemental nitrogen from urea and/ or soybean meal. J. Dairy Sci. 61:902-915.

Wohlt, J. E., S. L. Chmiel, P. K. Zajac, L. Backer, D. B. Blethen, and J. L. Evans. 1991. Dry matter intake, milk yield and composition, and nitrogen use in Holstein cows fed soybean, fish, or corn gluten meals. J. Dairy Sci. 74:1609-1622.

Wood, P. D. P. 1967. Algebraic model of the lactation curve in cattle. Nature 216:164.

Wood, P. D. P. 1968. Factors affecting persistency of lactation in cattle. Nature 218:894.

Wood, P. D. P. 1969. Factors affecting the shape of the lactation curve in cattle. Anim. Prod. 11:307-316.

Wood, P. D. P. 1976. Algebraic models of the lactation curves for milk, fat and protein production, with estimates of seasonal variation. Anim. Prod. 22:35-40.

Wood, P. D. P. 1977. The biometry of lactation. J. Agric. Sci. 88:333-339.

Wood, P. D. P. 1979. A simple model of lactation curves for milk yield, food requirement and body weight. Anim. Prod. 28:55-63. 